\title{
The genus Milnesium Doyère, 1840 (Tardigrada) in South America with descriptions of two new species from Argentina and discussion of the feeding behaviour in the family Milnesiidae
}

\author{
Milena Roszkowska ${ }^{1,2^{*}}$, Marta Ostrowska ${ }^{1}$ and Łukasz Kaczmarek ${ }^{1,2}$
}

\begin{abstract}
Background: The diversity and distribution of the tardigrades in South America are rather poor and selective, as is information about their feeding behaviour and diet. To date, only ca. 210 tardigrade taxa have been reported from the region of South America. In the present paper, we provide an update of the distribution of the genus Milnesium in South America and discuss some aspects of the feeding behaviour in the family Milnesiidae.

Results: In seven moss samples collected in the Argentinean province of Río Negro, 31 specimens, 4 exuviae and 32 eggs belonging to the genus Milnesium were found. Among them, four species were identified: Milnesium argentinum sp. nov., Milnesium beatae sp. nov., Milnesium brachyungue and Milnesium granulatum. By its dorsal sculpture, M. argentinum sp. nov. is most similar to M. beatae sp. nov., Milnesium beasleyi and Milnesium berladnicorum, but it differs from $M$. beasleyi and $M$. berladnicorum mainly by having a different claw configuration and from $M$. beatae and $M$. beasleyi by having stylet supports inserted in a more caudal position and by some other morphometric characters. In the width of its buccal tube and the claw configuration [3-3]-[3-3], M. beatae sp. nov. is most similar to Milnesium bohleberi, M. brachyungue and Milnesium eurystomum, but it differs from them mainly by having a sculptured dorsal cuticle and by some other morphometric characters.

Conclusions: The study discusses distribution and taxonomic problems of the Milnesium species known from South America. As of now, nine Milnesium taxa are known from this region (including two new species reported in this paper). Additionally, the study broadens our knowledge of tardigrades' feeding behaviour, provides some details about their diet and suggests that the type of prey chosen by some species belonging to the family Milnesiidae may be associated with the width of their buccal tube.
\end{abstract}

Keywords: Milnesiidae; Milnesium argentinum sp. nov; Milnesium beatae sp. nov; Nahuel Huapi National Park; Neotropical region; New records; Prey selection; Río Negro; Taxonomy; Water bears

\section{Background}

South America, with an area of almost 18 million $\mathrm{km}^{2}$, is located mostly in the Southern Hemisphere, with a relatively small portion (ca. 10\%) in the Northern Hemisphere. It includes 12 sovereign countries. Geographically, the western part of South America is dominated by

\footnotetext{
* Correspondence: mil.roszkowska@gmail.com
${ }^{1}$ Department of Animal Taxonomy and Ecology, Faculty of Biology, Adam

* Correspondence: mil.roszkowska@gmail.com
${ }^{1}$ Department of Animal Taxonomy and Ecology, Faculty of Biology, Adam Mickiewicz University in Poznań, Umultowska 89, 61-614, Poznań, Poland ${ }^{2}$ Laboratorio de Ecología Natural y Aplicada de Invertebrados, Universidad
Estatal Amazónica, Campus Principal Km 2.1/2 via a Napo (Paso Lateral) Puyo, 'Laboratorio de Ecología Natural y Aplicada de Invertebrados, Universidad
Estatal Amazónica, Campus Principal Km 2.1/2 via a Napo (Paso Lateral) Puyo, Pastaza, Ecuador
}

\section{Springer}

the Andes while the eastern part contains both highland regions and large river basins such as the Amazon, Paraná and Orinoco. Most of the continent lies in the tropics and the entire South American territory belongs to Neotropical ecozone (Peel et al. 2007, Holt et al. 2013).

Argentina, located in southern part of the continent, shares land borders with Chile across the Andes to the west, Bolivia and Paraguay to the north, Brazil to the northeast, Uruguay and the South Atlantic Ocean to the east and the Drake Passage to the south. Argentina is the eighth largest country in the world and the second 
largest in Latin America. It is subdivided into 23 provinces and one autonomous city - Buenos Aires. The exceptionally diverse climate depends on the geographic regional division and ranges from tropical in the north to subpolar in the far continental south (Edwards 2008).

Río Negro, one of the 23 provinces of Argentina, is located at the northern edge of Patagonia. The central region of the province is dominated by a series of plateaus and isolated hills with altitude ranging from 600 to $1,000 \mathrm{~m}$ asl. Towards the west, the foothills of the Andes are dominated by a series of low valleys. The climate of the province is temperate at low elevations and very harsh in the highest Andean peaks (Edwards 2008).

The Phylum Tardigrada consists currently of ca. 1,200 species (Guidetti and Bertolani 2005; Degma and Guidetti 2007; Vicente and Bertolani 2013; Degma et al. 2009-2014) that inhabit terrestrial and aquatic (freshwater and marine) environments throughout the world (Ramazzotti and Maucci 1983). Our knowledge of the diversity and distribution of South American water bears is poor and selective. To date, ca. 210 taxa (including seven Milnesium species) have been reported from this region (mostly from Argentina, Chile and Brazil) (McInnes 1994; Binda and Pilato 1994a,b, 1999a,b; Pilato and Binda 1994, 1996, 1998; Maucci 1996; Claps and Rossi 1997; Claxton 1998; Pilato and Patanè 1998; Dastych et al. 1998; Pilato et al. 1998, 2000, 2001, 2002, 2003, 2004; Dastych 1999a,b, 2000, Pilato 2000, 2007; Jerez Jaimes and Narváez Parra 2001; Nickel et al. 2001; Peluffo et al. 2002, 2007; Michalczyk and Kaczmarek 2003, 2004, 2005, 2006; Marley 2006; Moly de Peluffo et al. 2006; Degma et al. 2008; Kaczmarek and Michalczyk 2009; Rossi et al. 2009; Montoya et al. 2010; Lisi 2011; Guidetti et al. 2013; Meyer 2013; Kaczmarek et al. 2014a, b; Lisi et al. 2014; Melo et al. 2014).

The genus Milnesium (Doyère 1840) is known from many localities, from the Antarctic through tropical and temperate to Arctic regions (Michalczyk et al. 2012a,b). Since the genus was recently redescribed (Michalczyk et al. 2012a,b), many new records and species have been reported from various localities throughout the world (e.g. Kaczmarek et al. 2012a,b, 2014b; Meyer and Hinton 2012; Johansson et al. 2013; Hinton et al. 2013; Meyer et al. 2013, 2014; Shaw and Miller 2013; Trygvadóttir and Kristensen 2013; Bartels et al. 2014; Ciobanu et al. 2014a,b; Lisi et al. 2014; Zawierucha et al. 2014; Melo et al. 2014). Taking into consideration that some morphological characters were not mentioned in older records of the genus members, all the Milnesium records before 2012 should be verified (Michalczyk et al. 2012a,b). Until now in South America, only seven Milnesium species have been reported (see the 'Results' section). In this paper, two new species of this genus are described and illustrated. Additionally, two new records of Milnesium species for Argentina are given. The distribution and taxonomic problems of all Milnesium species known from South America are also discussed.

All Milnesium species, with their wide and relatively short buccal tube connected with a large pharynx without placoids, are considered carnivorous, but details of their diet are still very poorly known. They can feed on rotiferas, nematodes, other tardigrades or even on amoebas (e.g. Kinchin 1990; Suzuki 2003; Nelson et al. 2010; Miller and Williams 2012). In this paper, we discuss some details of the diet of Milnesium species (and more general the entire family Milnesiidae) in connection with the different constructions of the buccal tube.

\section{Methods}

Seven moss samples were collected from trees and rocks from various localities in Nahuel Huapi National Park (Patagonia, southern Argentina) in 2006 and 2012 by Dawid Diduszko, Łukasz Kaczmarek and Marta Prange (see the 'List of samples' section) and four species of the genus Milnesium were found. All samples were collected and examined for tardigrades using standard methods (Dastych 1980; Ramazzotti and Maucci 1983). After extraction, all specimens, exuviae and eggs were fixed and mounted on microscope slides in Hoyer's medium. Observations, measurements and photomicrographs were taken using phase contrast microscopy (PCM) (Olympus BX41 with digital camera ARTCAM-300Mi, Olympus Corporation, Shinjuku-ku, Japan). All measurements (determined with QuickPhoto Camera 2.3) are given in micrometres $[\mu \mathrm{m}]$.

Morphometric data were handled using the 'Apochela' ver. 1.1 template available from the Tardigrada Register (Michalczyk and Kaczmarek 2013). Structures were measured only if their orientations were suitable. Body length was measured from the anterior to the posterior end of the body, excluding the hind legs. All measurements followed protocols in Tumanov (2006). Buccal tube width was measured at three points as suggested by Michalczyk et al. (2012a,b). The $p t$ ratio is the ratio of the length of a given structure to the length of the buccal tube, expressed as a percentage (Pilato 1981). The $p t$ values are always provided in [square brackets and in italics]. Configuration of the number of claw points on the secondary branches ('claw configuration') is given according to Michalczyk et al. (2012a,b).

Species were identified using the keys in Michalczyk et al. (2012a,b) and other original descriptions/re-descriptions (Binda and Pilato 1990; Ramazzotti 1962; Kaczmarek et al. 2012a, b; Michalczyk et al. 2012a,b). Characteristics and measurements of the species used in the differential diagnosis are given according to the original descriptions (Ramazzotti 1962; Binda and Pilato 1990; Maucci 1991; Pilato et al. 2002; Kaczmarek et al. 2004, 2012a, b; Tumanov 2006; Kaczmarek and Michalczyk 2007; 
Meyer and Hinton 2010, 2012; Michalczyk et al. 2012a, b; Bartels et al. 2014; Ciobanu et al. 2014b) or are based on direct examination of fixed specimens (holotype and paratypes of $M$. beasleyi, $M$. berladnicorum, $M$. bohleberi, M. granulatum, M. katarzynae, M. krzysztofi and specimens of M. eurystomum from Spitsbergen). Tardigrade taxonomy follows Marley et al. (2011). In the list of the species, we use Roman numerals to indicate the sample code (see the 'List of samples' and 'Results' sections) and Arabic numerals to designate the number of specimens and eggs (see the 'Results' section).

Raw data underlying the description of Milnesium argentinum sp. nov. and Milnesium beatae sp. nov. are deposited in the Tardigrada Register (Michalczyk and Kaczmarek 2013) under http://www.tardigrada.net/register/0015.htm and http://www.tardigrada.net/register/0016. $\mathrm{htm}$, respectively.

\section{List of samples}

I. $41^{\circ} 20^{\prime} \mathrm{S}, 71^{\circ} 30^{\prime} \mathrm{W}$, ca. $850 \mathrm{~m}$ asl: Río Negro, Nahuel Huapi National Park, Bariloche, Mirador Lago Mascardi, moss from rock, coll. Dawid Diduszko, 22 February 2012.

II. $41^{\circ} 12^{\prime} \mathrm{S}, 71^{\circ} 50^{\prime} \mathrm{W}$, ca. 1,000 m asl: Río Negro, Nahuel Huapi National Park, Ventisquero Negro, car parking near small bar, Nothofagus forest, moss from rocks, coll. Łukasz Kaczmarek, 27 January 2006.

III. $41^{\circ} 12^{\prime} \mathrm{S}, 71^{\circ} 50^{\prime} \mathrm{W}$, ca. $1,000 \mathrm{~m}$ asl: Río Negro, Nahuel Huapi National Park, Ventisquero Negro, car parking near small bar, Nothofagus forest, moss from rocks, coll. Łukasz Kaczmarek, 27 January 2006.

IV. $41^{\circ} 12^{\prime} \mathrm{S}, 71^{\circ} 50^{\prime} \mathrm{W}$, ca. 1,000 m asl: Río Negro, Nahuel Huapi National Park, Ventisquero Negro, car parking near small bar, Nothofagus forest, moss from rocks, coll. Łukasz Kaczmarek, 27 January 2006.

V. $41^{\circ} 12^{\prime} \mathrm{S}, 71^{\circ} 50^{\prime} \mathrm{W}$, ca. $1,000 \mathrm{~m}$ asl: Río Negro, Nahuel Huapi National Park, Ventisquero Negro, car parking near small bar, Nothofagus forest, moss from tree, coll. Łukasz Kaczmarek, 27 January 2006.

VI. $41^{\circ} 12^{\prime} \mathrm{S}, 71^{\circ} 28^{\prime} \mathrm{W}$, ca. $1,400 \mathrm{~m}$ asl: Río Negro, Nahuel Huapi National Park, Bariloche, $1.5 \mathrm{~km}$ from Refugio Frey, Nothofagus forest, moss from stone, coll. Marta Prange, 26 January 2006.

VII. $41^{\circ} 13^{\prime} \mathrm{S}, 71^{\circ} 27^{\prime} \mathrm{W}$, ca. 1,200 m asl: Río Negro, Nahuel Huapi National Park, on the trail to Refugio Frey, near to Van Titter stream, Nothofagus forest, moss from stone, coll. Marta Prange, 26 January 2006.

\section{Results}

\section{Taxonomic account}

Phylum: Tardigrada Doyère 1840.

Class: Eutardigrada Richters 1926.

Order: Apochela Schuster et al. 1980.
Family: Milnesiidae Ramazzotti 1962.

Genus: Milnesium Doyère 1840.

\section{Milnesium argentinum sp. nov.}

http://www.tardigrada.net/register/0015.htm.

Material examined: Eighteen females, all from Nahuel Huapi National Park, Río Negro, Argentina, mosses samples from rocks and stones, coll. Dawid Diduszko, Łukasz Kaczmarek and Marta Prange.

Type material: Holotype and three paratypes in sample VII.

Additional material: two specimens in sample I, ten specimens in sample III and two specimens in sample IV.

\section{Diagnosis}

Adults (Figure 1a) (measurements in micrometres, pt ratios and statistics in Table 1): The body rose before fixation and transparent afterwards, eyes present. Cuticle sculptured with pseudopores (0.4 to 0.7) not arranged in bands, sparsely distributed and not forming reticular design (Figure 2b). Six peribuccal papillae and six peribuccal lamellae around the mouth opening present. Two cephalic papillae positioned laterally. Peribuccal and cephalic papillae similar in length.

Buccal apparatus of the Milnesium type (Figure 2a). Buccal tube rather narrow and long (standard width on average $27 \%$ of its length) and funnel-shaped, wider anteriorly (posterior diameter on average $80 \%$ of the anterior diameter). Pharyngeal bulb elongated, pear-shaped and without placoids or septulum.

Claws of the Milnesium type, slender (Figure 3a,b). Primary branches on all legs with small but distinct accessory points detaching from the branch at its greatest curvature (Figure 3b). Secondary branches with rounded basal thickenings (Figure $3 \mathrm{~b}$ ). All secondary branches on all legs with three points (claw configuration: [3-3]-[3-3]). Single, long transverse, cuticular bars under claws I to III present (Figure 3a).

Eggs: Oval, smooth and deposited in exuvium as in all other known Milnesium species.

Males not observed.

Locus typicus: Argentina, $41^{\circ} 13^{\prime} \mathrm{S}, 71^{\circ} 27^{\prime} \mathrm{W}$, ca. $1,200 \mathrm{~m}$ asl., Río Negro Province, Nahuel Huapi National Park.

Etymology: The new species is named after the country of Argentina, where the species was collected.

Type depositories: The holotype and 14 paratypes are deposited in the Department of Animal Taxonomy and Ecology, Adam Mickiewicz University in Poznań, Umultowska 89, Poznań, Poland; two paratypes are deposited at the Natural History Museum, University of Copenhagen Universitetsparken 15, DK-2100 Copenhagen, Denmark and one paratype is deposited at collection of 


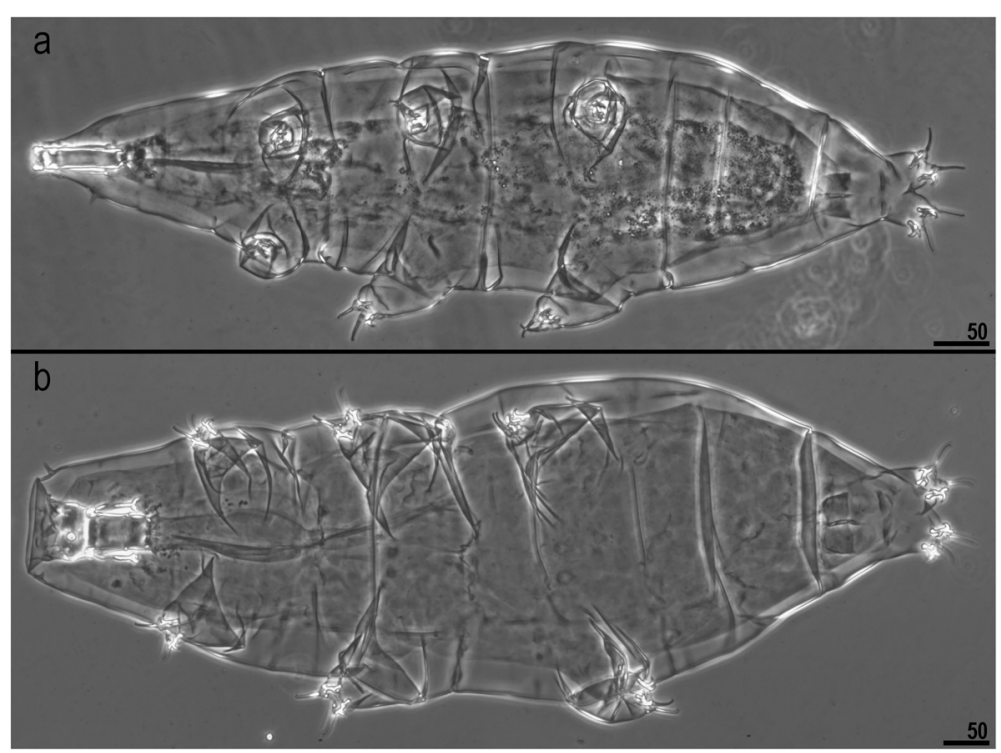

Figure 1 Milnesium argentinum sp. nov. and Milnesium beatae sp. nov. Milnesium argentinum sp. nov.: (a) habitus (ventral view) and Milnesium beatae sp. nov.: (b) habitus (ventral view) (both PCM).

Binda and Pilato, Museum of the Department of Animal Biology 'Marcello La Greca', University of Catania, Italy.

\section{Differential diagnosis}

Based on having a sculptured dorsal cuticle, $M$. argentinum sp. nov. belongs to the granulatum group (Michalczyk et al. 2012a,b). The new species with three points on the secondary branches of all claws (claw configuration [3-3]-[3-3]) is most similar to M. beasleyi Kaczmarek et al. 2012a, b, M. beatae sp. nov. and $M$. berladnicorum Ciobanu et al. 2014b, but it differs from the following:

1. M. beasleyi, known only from Turkey (Kaczmarek et al. 2012a, b) by different claw configuration ([33]-[3-3] in M. argentinum sp. nov. vs. [2-3]-[3-2] in $M$. beasleyi), presence of rounded basal thickenings under secondary branches of claws, stylet supports inserted in more caudal position ([70.0-73.7] in $M$. argentinum sp. nov. vs. [61.6-65.6] in M. beasleyi) and slightly smaller claws I to IV (see Table 1 and Table one in Kaczmarek et al. (2012a, b) for the exact differences in dimensions of claws).

2. M. beatae sp. nov. by stylet supports inserted in more caudal position ([70.0-73.7] in $M$. argentinum sp. nov. vs. [63.8-66.7] in M. beatae sp. nov.), smaller $p t$ of width of buccal tube ([30.3-39.8], [24.2-32.3], [23.1-33.6] anterior, standard and posterior, respectively, in $M$. argentinum sp. nov. vs. [70.3-78.9], [58.1-65.6], [49.4-56.5] anterior, standard and posterior, respectively, in $M$. beatae sp. nov.) and smaller claws I to IV (see Tables 1 and 2 for the exact differences in dimensions of claws).
3. M. berladnicorum, known only from Romania (Ciobanu et al. 2014b) by different claw configuration ([3-3]-[3-3] in M. argentinum sp. nov. vs. [2-3]-[2-2] in M. berladnicorum) and smaller claws I to IV (see Table 1 and Table one in Ciobanu et al. (2014a, b) for the exact differences in dimensions of claws).

Besides the species mentioned above, $M$. argentinum sp. nov. is similar to other species of the genus Milnesium with the claw configuration [3-3]-[3-3] (M. alabamae Wallendorf and Miller 2009, M. antarcticum Tumanov 2006, M. asiaticum Tumanov 2006, M. barbadosense Meyer and Hinton 2012, M. bohleberi Bartels et al. 2014, M. brachyungue Binda and Pilato 1990, M. eurystomum Maucci 1991, M. granulatum Ramazzotti 1962, M. longiungue Tumanov 2006 and M. zsalakoae Meyer and Hinton 2010) or sculptured cuticle (M. beasleyi Kaczmarek et al. 2012a, b, M. katarzynae Kaczmarek et al. 2004, M. krzysztofi Kaczmarek and Michalczyk 2007 and Milnesium reticulatum Pilato et al. 2002).

The new species differs from the following:

4. M. alabamae, known only from the USA (Wallendorf and Miller 2009) by different dorsal sculpture (pseudopores not arranged in bands, sparsely distributed and not forming a reticular design in $M$. argentinum sp. nov. vs. pseudopores arranged in bands (especially in caudal region), densely distributed and forming a reticular design in M. alabamae), presence of accessory points on main branches of claws, presence of eyes and stylet 
Table 1 Measurements and pt values of selected morphological structures of Milnesium argentinum sp. nov. mounted in Hoyer's medium

\begin{tabular}{|c|c|c|c|c|c|c|c|c|c|c|c|c|c|}
\hline \multirow{3}{*}{$\begin{array}{l}\text { Character } \\
\text { Body length }\end{array}$} & \multirow{3}{*}{$\begin{array}{l}\boldsymbol{N} \\
12\end{array}$} & \multicolumn{6}{|c|}{ Range } & \multicolumn{2}{|c|}{ Mean } & \multicolumn{2}{|c|}{ SD } & \multicolumn{2}{|c|}{ Holotype } \\
\hline & & \multicolumn{3}{|c|}{$\mu \mathrm{m}$} & \multicolumn{3}{|c|}{$p t$} & \multirow{2}{*}{$\begin{array}{l}\boldsymbol{\mu m} \\
707\end{array}$} & \multirow{2}{*}{$\begin{array}{l}\boldsymbol{p t} \\
1,093\end{array}$} & \multirow{2}{*}{$\begin{array}{l}\boldsymbol{\mu m} \\
141\end{array}$} & \multirow{2}{*}{$\begin{array}{l}\boldsymbol{p t} \\
123\end{array}$} & \multirow{2}{*}{$\begin{array}{l}\boldsymbol{\mu m} \\
890\end{array}$} & \multirow{2}{*}{$\frac{p t}{1,21}$} \\
\hline & & 445 & - & 890 & 921 & - & 1,290 & & & & & & \\
\hline Peribuccal papillae length & 10 & 6.7 & - & 12.4 & 14.1 & - & 18.6 & 10.3 & 16.3 & 1.7 & 1.1 & 11.6 & 15.8 \\
\hline Lateral papillae length & 9 & 5.5 & - & 11.4 & 9.4 & - & 17.6 & 9.0 & 14.1 & 1.9 & 2.3 & $?$ & $?$ \\
\hline \multicolumn{14}{|l|}{ Buccal tube } \\
\hline Length & 12 & 47.6 & - & 74.2 & & - & & 64.3 & - & 8.6 & - & 73.5 & - \\
\hline Stylet support insertion point & 12 & 35.1 & - & 52.3 & 70.0 & - & 73.7 & 46.0 & 71.7 & 5.8 & 1.4 & 52.3 & 71.2 \\
\hline Anterior width & 12 & 16.0 & - & 29.5 & 30.3 & - & 39.8 & 22.3 & 34.5 & 4.3 & 3.4 & 29.1 & 39.6 \\
\hline Standard width & 12 & 13.0 & - & 24.0 & 24.2 & - & 32.3 & 17.7 & 27.4 & 3.5 & 2.8 & 22.0 & 29.9 \\
\hline Posterior width & 12 & 12.2 & - & 24.5 & 23.1 & - & 33.6 & 17.8 & 27.6 & 3.9 & 3.4 & 24.5 & 33.3 \\
\hline Standard width/length ratio & 12 & $24 \%$ & - & $32 \%$ & & - & & $27 \%$ & - & $3 \%$ & - & $30 \%$ & - \\
\hline Posterior/anterior width ratio & 12 & $76 \%$ & - & $87 \%$ & & - & & $80 \%$ & - & $4 \%$ & - & $84 \%$ & - \\
\hline \multicolumn{14}{|l|}{ Claw 1 lengths } \\
\hline External primary branch & 10 & 12.4 & - & 20.5 & 24.3 & - & 28.6 & 16.7 & 26.3 & 2.6 & 1.5 & 20.5 & 27.9 \\
\hline External base + secondary branch & 9 & 10.5 & - & 17.8 & 22.0 & - & 25.2 & 14.4 & 23.0 & 2.4 & 1.2 & 17.8 & 24.2 \\
\hline External spur & 8 & 3.7 & - & 5.8 & 7.1 & - & 8.2 & 4.8 & 7.7 & 0.8 & 0.4 & $?$ & $?$ \\
\hline Internal primary branch & 11 & 12.9 & - & 18.7 & 21.1 & - & 28.9 & 15.8 & 24.8 & $2 . .1$ & 2.0 & 17.4 & 23.7 \\
\hline Internal base + secondary branch & 10 & 11.1 & - & 18.2 & 21.1 & - & 26.1 & 14.8 & 23.2 & 2.5 & 1.5 & 17.3 & 23.5 \\
\hline Internal spur & 10 & 3.4 & - & 5.7 & 7.1 & - & 8.8 & 5.0 & 7.8 & 0.9 & 0.6 & 5.6 & 7.6 \\
\hline \multicolumn{14}{|l|}{ Claw 2 lengths } \\
\hline External primary branch & 10 & 14.3 & - & 20.5 & 24.7 & - & 28.5 & 17.8 & 26.6 & 2.0 & 1.3 & 20.5 & 27.9 \\
\hline External base + secondary branch & 12 & 11.3 & - & 17.9 & 22.1 & - & 26.3 & 15.2 & 23.7 & 2.0 & 1.3 & 17.9 & 24.4 \\
\hline External spur & 6 & 2.8 & - & 5.5 & 5.9 & - & 8.5 & 4.0 & 6.7 & 1.0 & 1.0 & $?$ & $?$ \\
\hline Internal primary branch & 10 & 12.6 & - & 20.8 & 23.1 & - & 30.5 & 17.2 & 26.4 & 2.8 & 2.5 & 20.8 & 28.3 \\
\hline Internal base + secondary branch & 11 & 11.6 & - & 16.5 & 21.2 & - & 25.2 & 14.8 & 22.5 & 1.6 & 1.2 & 16.1 & 21.9 \\
\hline Internal spur & 9 & 3.8 & - & 6.3 & 6.6 & - & 8.8 & 5.3 & 7.9 & 0.9 & 0.8 & 6.3 & 8.6 \\
\hline \multicolumn{14}{|l|}{ Claw 3 lengths } \\
\hline External primary branch & 11 & 12.8 & - & 22.3 & 23.4 & - & 30.3 & 17.7 & 27.3 & 3.2 & 2.1 & 22.3 & 30.3 \\
\hline External base + secondary branch & 10 & 11.9 & - & 17.1 & 22.5 & - & 25.1 & 14.9 & 23.3 & 2.1 & 0.9 & 17.1 & 23.3 \\
\hline External spur & 7 & 3.3 & - & 5.3 & 5.9 & - & 7.6 & 4.5 & 6.9 & 0.8 & 0.6 & $?$ & $?$ \\
\hline Internal primary branch & 11 & 13.9 & - & 21.4 & 24.4 & - & 28.8 & 17.5 & 27.0 & 2.6 & 1.5 & 20.7 & 28.2 \\
\hline Internal base + secondary branch & 10 & 12.7 & - & 17.8 & 20.3 & - & 25.7 & 15.2 & 23.1 & 1.9 & 1.4 & 17.2 & 23.4 \\
\hline Internal spur & 8 & 4.2 & - & 6.9 & 6.8 & - & 9.9 & 5.7 & 8.5 & 1.0 & 1.1 & 6.2 & 8.4 \\
\hline \multicolumn{14}{|l|}{ Claw 4 lengths } \\
\hline Anterior primary branch & 10 & 14.7 & - & 24.3 & 29.9 & - & 33.8 & 20.5 & 31.8 & 3.6 & 1.3 & 24.2 & 32.9 \\
\hline Anterior base + secondary branch & 11 & 12.2 & - & 20.3 & 24.4 & - & 28.8 & 16.8 & 26.0 & 2.7 & 1.4 & 20.3 & 27.6 \\
\hline Anterior spur & 11 & 3.8 & - & 7.9 & 8.0 & - & 10.8 & 6.3 & 9.7 & 1.2 & 0.8 & 7.3 & 9.9 \\
\hline Posterior primary branch & 11 & 13.5 & - & 25.8 & 28.4 & - & 36.4 & 21.3 & 33.0 & 4.0 & 2.7 & 25.4 & 34.6 \\
\hline Posterior base + secondary branch & 11 & 12.8 & - & 20.2 & 25.0 & - & 28.3 & 17.3 & 26.8 & 2.7 & 1.0 & 20.2 & 27.5 \\
\hline Posterior spur & 8 & 3.3 & - & 6.2 & 6.9 & - & 8.4 & 4.9 & 7.8 & 1.0 & 0.6 & 6.2 & 8.4 \\
\hline
\end{tabular}

Range refers to the smallest and the largest structure among all measured specimens.

The $p t$ values are provided in italics.

$N$, number of specimens/structures measured; SD, standard deviation; ?, no data. 


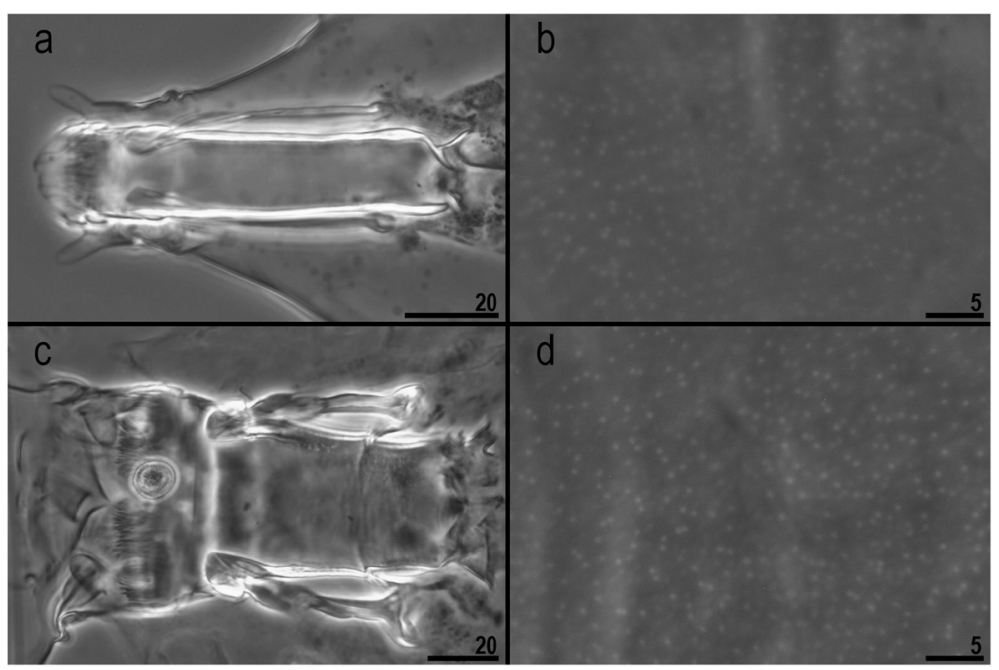

Figure 2 Milnesium argentinum sp. nov. and Milnesium beatae sp. nov. Milnesium argentinum sp. nov.: (a) buccal tube (ventral view); (b) dorsal cuticle with pseudopores and Milnesium beatae sp. nov.: (c) buccal tube (ventral view); (d) dorsal cuticle with pseudopores (all PCM).

supports inserted in more caudal position ([70.0-73.7] in M. argentinum sp. nov. vs. [63.7] in $M$. alabamae (in specimen 514.9 in length)).

5. M. antarcticum, known only from Antarctica (Tumanov 2006) by having sculptured dorsal cuticle and slightly smaller claws I to IV (see Table 1 and Table two in Tumanov (2006) for the exact differences in dimensions of claws).
6. M. asiaticum, known only from Kirghizia, Romania and Svalbard (Tumanov 2006; Kaczmarek et al. 2012a, b; Ciobanu et al. 2014a, b) by having sculptured dorsal cuticle and stylet supports inserted in more caudal position ([70.0-73.7] in $M$. argentinum sp. nov. vs. [63.9-66.9] in $M$. asiaticum).

7. M. barbadosense, known only from Barbados (Meyer and Hinton 2012) by having sculptured dorsal

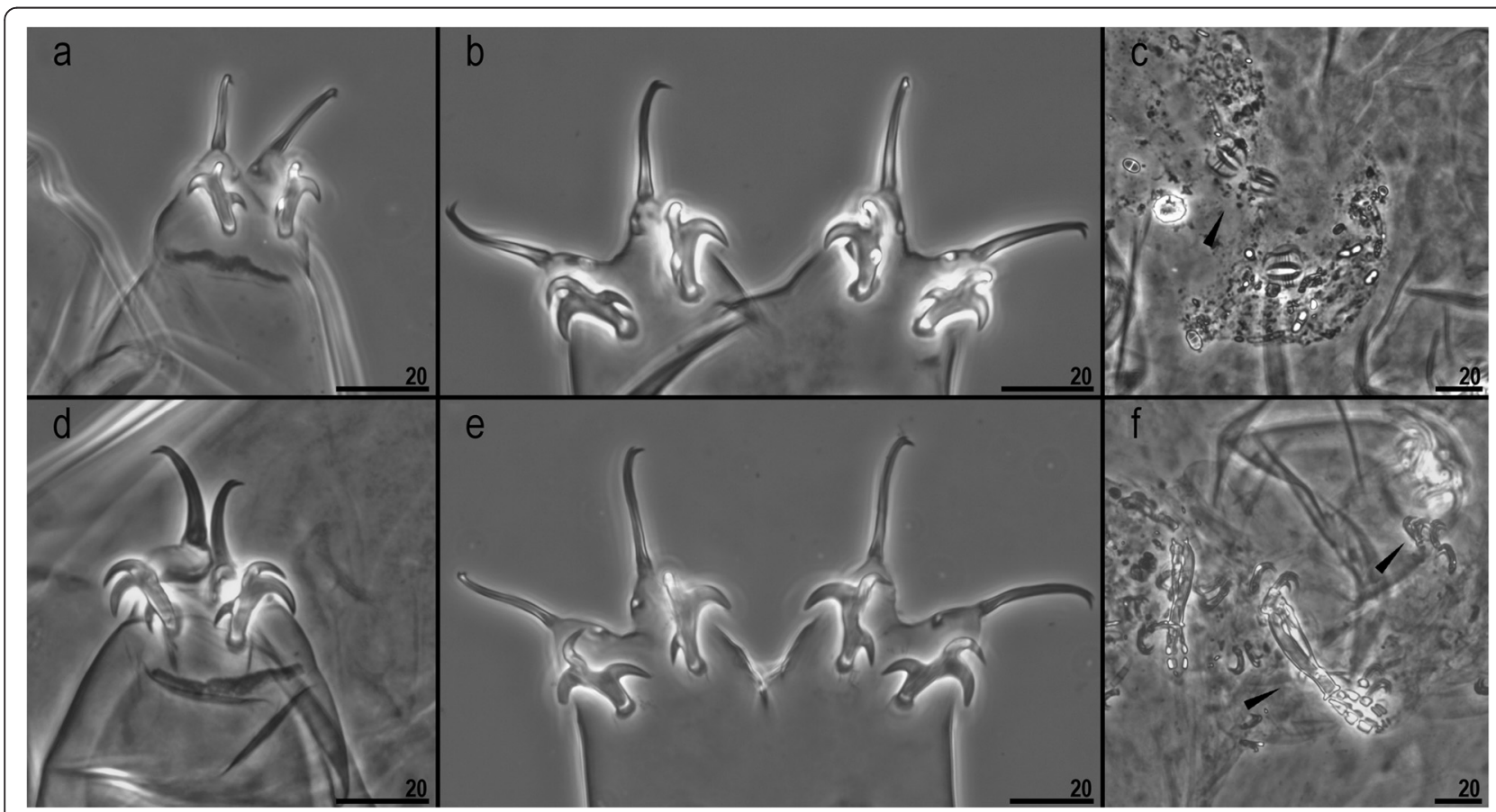

Figure 3 Milnesium argentinum sp. nov. and Milnesium beatae sp. nov. Milnesium argentinum sp. nov.: (a) claws II; (b) claws IV; (c) rotifer mastaxes in the gut (black arrowhead) and Milnesium beatae sp. nov.: (d) claws I; (e) claws IV; (f) tardigrade buccal apparatuses and claws in the gut (black arrowheads) (all PCM). 
Table 2 Measurements and pt values of selected morphological structures of Milnesium beatae sp. nov. mounted in Hoyer's medium

\begin{tabular}{|c|c|c|c|c|c|c|c|c|c|c|c|c|c|}
\hline \multirow{3}{*}{$\begin{array}{l}\text { Character } \\
\text { Body length }\end{array}$} & \multirow{3}{*}{$\begin{array}{l}N \\
7\end{array}$} & \multicolumn{6}{|c|}{ Range } & \multicolumn{2}{|c|}{ Mean } & \multicolumn{2}{|c|}{ SD } & \multicolumn{2}{|c|}{ Holotype } \\
\hline & & \multicolumn{3}{|c|}{$\mu \mathrm{m}$} & \multicolumn{3}{|c|}{$p t$} & \multirow{2}{*}{$\begin{array}{l}\boldsymbol{\mu m} \\
864\end{array}$} & \multirow{2}{*}{$\frac{p t}{1,401}$} & \multirow{2}{*}{$\begin{array}{l}\boldsymbol{\mu m} \\
144\end{array}$} & \multirow{2}{*}{$\begin{array}{c}\boldsymbol{p t} \\
97\end{array}$} & \multirow{2}{*}{$\begin{array}{l}\boldsymbol{\mu m} \\
979\end{array}$} & \multirow{2}{*}{$\begin{array}{l}\boldsymbol{p t} \\
1,49\end{array}$} \\
\hline & & 662 & - & 1,011 & 1,259 & - & 1,524 & & & & & & \\
\hline Peribuccal papillae length & 7 & 9.8 & - & 13.2 & 18.0 & - & 23.6 & 12.0 & 19.7 & 1.1 & 1.9 & 13.2 & 20.2 \\
\hline Lateral papillae length & 6 & 10.0 & - & 14.8 & 19.0 & - & 21.1 & 12.8 & 20.2 & 1.6 & 0.9 & 13.2 & 20.2 \\
\hline \multicolumn{14}{|l|}{ Buccal tube } \\
\hline Length & 7 & 51.6 & - & 70.2 & & - & & 61.4 & - & 6.8 & - & 65.5 & - \\
\hline Stylet support insertion point & 7 & 33.8 & - & 45.0 & 63.8 & - & 66.7 & 40.0 & 65.1 & 4.3 & 1.1 & 43.3 & 66.1 \\
\hline Anterior width & 7 & 37.0 & - & 53.5 & 70.3 & - & 78.9 & 45.7 & 74.3 & 6.6 & 3.7 & 51.7 & 78.9 \\
\hline Standard width & 7 & 32.0 & - & 42.5 & 58.1 & - & 65.6 & 38.0 & 61.9 & 4.2 & 2.6 & 39.2 & 59.8 \\
\hline Posterior width & 7 & 25.7 & - & 39.0 & 49.4 & - & 56.5 & 33.1 & 53.6 & 5.2 & 2.8 & 37.0 & 56.5 \\
\hline Standard width/length ratio & 7 & $58 \%$ & - & $66 \%$ & & - & & $62 \%$ & - & $3 \%$ & - & $60 \%$ & - \\
\hline Posterior/anterior width ratio & 7 & $69 \%$ & - & $76 \%$ & & - & & $72 \%$ & - & $3 \%$ & - & $72 \%$ & - \\
\hline \multicolumn{14}{|l|}{ Claw 1 lengths } \\
\hline External primary branch & 7 & 17.9 & - & 26.4 & 33.6 & - & 41.4 & 22.0 & 35.8 & 3.1 & 2.7 & 22.0 & 33.6 \\
\hline External base + secondary branch & 6 & 13.6 & - & 22.1 & 26.4 & - & 34.6 & 19.0 & 30.9 & 3.8 & 3.0 & 20.8 & 31.8 \\
\hline External spur & 4 & 5.0 & - & 6.5 & 8.0 & - & 10.3 & 5.6 & 9.2 & 0.7 & 1.0 & 5.8 & 8.9 \\
\hline Internal primary branch & 6 & 16.4 & - & 25.4 & 31.2 & - & 39.8 & 22.0 & 34.9 & 3.2 & 3.0 & 23.6 & 36.0 \\
\hline Internal base + secondary branch & 6 & 13.9 & - & 22.3 & 26.9 & - & 33.4 & 19.1 & 30.9 & 3.8 & 3.0 & 21.5 & 32.8 \\
\hline Internal spur & 5 & 4.4 & - & 7.4 & 8.5 & - & 10.5 & 5.8 & 9.5 & 1.2 & 0.8 & $?$ & $?$ \\
\hline \multicolumn{14}{|l|}{ Claw 2 lengths } \\
\hline External primary branch & 7 & 19.1 & - & 27.3 & 36.9 & - & 42.4 & 24.5 & 39.8 & 3.6 & 2.3 & 27.3 & 41.7 \\
\hline External base + secondary branch & 6 & 14.8 & - & 22.9 & 28.7 & - & 34.1 & 19.4 & 31.6 & 3.4 & 2.1 & 21.1 & 32.2 \\
\hline External spur & 5 & 5.5 & - & 7.9 & 8.0 & - & 12.1 & 6.3 & 10.5 & 1.1 & 1.5 & 7.9 & 12.1 \\
\hline Internal primary branch & 6 & 18.6 & - & 25.4 & 35.4 & - & 37.4 & 22.2 & 36.3 & 2.9 & 0.7 & 24.5 & 37.4 \\
\hline Internal base + secondary branch & 7 & 14.4 & - & 21.8 & 27.9 & - & 33.3 & 19.1 & 31.0 & 3.1 & 2.2 & 21.8 & 33.3 \\
\hline Internal spur & 6 & 5.2 & - & 7.7 & 10.1 & - & 12.3 & 6.5 & 10.6 & 1.1 & 0.9 & 6.8 & 10.4 \\
\hline \multicolumn{14}{|l|}{ Claw 3 lengths } \\
\hline External primary branch & 7 & 18.4 & - & 26.7 & 35.7 & - & 41.4 & 23.8 & 38.7 & 3.5 & 2.6 & 26.7 & 40.8 \\
\hline External base + secondary branch & 6 & 14.8 & - & 22.9 & 28.7 & - & 36.5 & 19.8 & 32.5 & 3.6 & 3.0 & $?$ & $?$ \\
\hline External spur & 5 & 4.7 & - & 6.9 & 8.9 & - & 10.5 & 5.9 & 9.7 & 1.1 & 0.7 & $?$ & $?$ \\
\hline Internal primary branch & 5 & 17.6 & - & 26.4 & 34.1 & - & 41.2 & 22.9 & 37.8 & 4.4 & 3.2 & $?$ & $?$ \\
\hline Internal base + secondary branch & 6 & 15.5 & - & 23.1 & 29.8 & - & 36.8 & 20.0 & 32.6 & 3.4 & 2.7 & 21.7 & 33.1 \\
\hline Internal spur & 5 & 5.8 & - & 8.9 & 10.5 & - & 14.2 & 7.3 & 11.9 & 1.1 & 1.4 & 6.9 & 10.5 \\
\hline \multicolumn{14}{|l|}{ Claw 4 lengths } \\
\hline Anterior primary branch & 6 & 23.5 & - & 31.5 & 43.1 & - & 49.4 & 28.7 & 45.6 & 2.9 & 2.5 & 28.2 & 43.1 \\
\hline Anterior base + secondary branch & 6 & 17.7 & - & 25.5 & 33.4 & - & 40.0 & 22.9 & 36.4 & 2.8 & 3.2 & 21.9 & 33.4 \\
\hline Anterior spur & 5 & 6.4 & - & 10.0 & 12.2 & - & 14.2 & 8.2 & 13.0 & 1.3 & 0.8 & $?$ & $?$ \\
\hline Posterior primary branch & 6 & 24.0 & - & 32.6 & 45.3 & - & 51.5 & 30.0 & 47.5 & 3.4 & 2.5 & 32.6 & 49.8 \\
\hline Posterior base + secondary branch & 6 & 18.2 & - & 26.1 & 34.6 & - & 40.8 & 24.0 & 37.9 & 2.9 & 2.2 & 24.1 & 36.8 \\
\hline Posterior spur & 5 & 6.2 & - & 8.3 & 11.2 & - & 11.8 & 7.2 & 11.5 & 0.8 & 0.3 & $?$ & $?$ \\
\hline
\end{tabular}

Range refers to the smallest and the largest structure among all measured specimens.

The $p t$ values are provided in italics.

$N$, number of specimens/structures measured; SD, standard deviation; ?, no data. 
cuticle, presence of eyes and slightly smaller claws I to IV (see Table 1 and Table four in Meyer and Hinton (2012) for the exact differences in dimensions of claws).

8. M. bohleberi, known only from the USA (Bartels et al. 2014) by having sculptured dorsal cuticle, lower $p t$ of papillae length ([14.1-18.6], [9.4-17.6] peribuccal and lateral, respectively, in $M$. argentinum sp. nov. vs. [27.2-32.3], [17.7-21.2] peribuccal and lateral, respectively, in $M$. bohleberi), smaller $p t$ of width of buccal tube ([30.3-39.8], [24.2-32.3], [23.1-33.6] anterior, standard and posterior, respectively in $M$. argentinum sp. nov. vs. [63.4-74.7], [54.5-64.0], [52.4-62.0] anterior, standard and posterior, respectively in $M$. bohleberi) and smaller $p t$ of claws I to IV (see Table 1 and Table one in Bartels et al. (2014) for the exact differences in dimensions of claws).

9. M. brachyungue, known only from Argentina (present study) and Chile (Binda and Pilato 1990) by having sculptured dorsal cuticle and stylet supports inserted in more caudal position ([70.0-73.7] in $M$. argentinum sp. nov. vs. [69.4] in M. brachyungue (in specimen 729.0 in length)).

10. M. eurystomum, known from Argentina, Chile, Greenland, Mongolia (probably, see comments below), Spain, Svalbard and USA (Maucci 1991, 1996; Kaczmarek and Michalczyk 2006; Guil 2008; Kaczmarek et al. 2012a, b; Land et al. 2012; Johansson et al. 2013) by having sculptured dorsal cuticle, stylet supports inserted in more caudal position ([70.0-73.7] in M. argentinum sp. nov. vs. [60.0-60.3] in $M$. eurystomum) and smaller $p t$ of buccal tube width ([30.3-39.8], [24.2-32.3], [23.1-33.6] anterior, standard and posterior, respectively, in $M$. argentinum sp. nov. vs. [72.1-75.8], [61.8-64.8], [43.7-57.9] anterior, standard and posterior, respectively, in $M$. eurystomum).

11. M. granulatum, known from Argentina (present study), Chile, Colombia, Italy, Romania and the USA (Ramazzotti 1962; Ciobanu et al. 2014a, b; Bartels et al. 2014; Melo et al. (2014)) by different dorsal sculpture (pseudopores not arranged in bands, sparsely distributed and not forming reticular design in $M$. argentinum sp. nov. vs. pseudopores densely distributed and forming a reticular design in $M$. granulatum), stylet supports inserted in more caudal position ([70.0-73.7] in $M$. argentinum sp. nov. vs. [66.5] in $M$. granulatum (in specimen 338.3 in length)), smaller $p t$ of width of buccal tube ([30.3-39.8], [24.2-32.3], [23.1-33.6] anterior, standard and posterior, respectively, in $M$. argentinum sp. nov. vs. [46,3], [39.0], [40.1] anterior, standard and posterior, respectively, in $M$. granulatum (in specimen 338.3 in length)) and slightly smaller claws I to IV (see Table 1 and Table two in Michalczyk et al. (2012a,b) for the exact differences in dimensions of claws).

12. M. katarzynae, known from China, Colombia, Costa Rica and Taiwan (Kaczmarek et al. 2004, 2014a; Yin and Li 2011; Melo et al. (2014)) by different claw configuration ([3-3]-[3-3] in $M$. argentinum sp. nov. vs. [2-2]-[2-2] in $M$. katarzynae), different dorsal sculpture (pseudopores not arranged in bands, sparsely distributed and not forming a reticular design in $M$. argentinum sp. nov. vs. pseudopores densely distributed and forming a reticular design in $M$. katarzynae), presence of eyes and smaller summed $p t$ of external primary branches of claws I to IV([23.433.8] in M. argentinum sp. nov. vs. [40.0-43.8] in M. katarzynae).

13. M. krzysztofi, known from Colombia, Costa Rica and Peru (Kaczmarek and Michalczyk 2007; Kaczmarek et al. 2014a,b; Lisi et al. 2014; Melo et al. (2014)) by different claw configuration ([3-3]-[3-3] in M. argentinum sp. nov. vs. [2-3]-[3-2] in M. krzysztofi), different dorsal sculpture (pseudopores not arranged in bands, sparsely distributed and not forming a reticular design in $M$. argentinum sp. nov. vs. pseudopores densely distributed and forming a reticular design in M. krzysztofi), presence of eyes, stylet supports inserted in more caudal position ([70.0-73.7] in $M$. argentinum sp. nov. vs. [63.3-67.3] in M. krzysztofi), slightly lower $p t$ of buccal tube standard width ([24.2-32.3] in $M$. argentinum sp. nov. vs. [33.1-38.4] in M. krzysztofi) and slightly smaller claws I to IV (see Table 1 and Table one in Kaczmarek and Michalczyk (2007) for the exact differences in dimensions of claws).

14. M. longiungue, known only from India (Tumanov 2006) by having sculptured dorsal cuticle, presence of accessory points on main branches of claws, stylet supports inserted in more caudal position ([70.0-73.7] in M. argentinum sp. nov. vs. [59.1-66.7] in $M$. longiungue), lower $p t$ of standard buccal tube width ([24.2-32.3] in M. argentinum sp. nov. vs. [33.8-59.1] in M. longiungue) and slightly smaller claws I to IV (see Table 1 and Table six in Tumanov (2006) for the exact differences in dimensions of claws).

15. $M$. reticulatum, known only from Seychelles (Pilato et al. 2002) by different claw configuration ([3-3]-[3-3] in $M$. argentinum sp. nov. vs. [2-3]-[3-2] in $M$. reticulatum), different dorsal 
sculpture (pseudopores not arranged in bands, sparsely distributed and not forming a reticular design in $M$. argentinum sp. nov. vs. pseudopores arranged in nine sculptured bands, forming a reticular design in $M$. reticulatum), absence of cuticular gibbosities, having six peribuccal lamellae (four in $M$. reticulatum), stylet supports inserted in more caudal position ([70.0-73.7] in M. argentinum sp. nov. vs. [68.5-69.8] in $M$. reticulatum) and slightly smaller claws I to IV (see Table 1 and Table two in Pilato et al. (2002) for the exact differences in dimensions of claws).

16. M. zsalakoae, known only from Arizona and New Mexico, U.S.A. (Meyer and Hinton 2010) by having sculptured dorsal cuticle, presence of accessory points on main branches of claws, lower $p t$ of buccal tube standard width ([24.2-32.3] in $M$. argentinum sp. nov. vs. [36.8-41.9] in M. zsalakoae) and smaller summed $p t$ of internal claws and spurs I to IV (internal primary branch [21.1-36.4], internal base + secondary branch [20.3-28.3], internal spur [6.6-9.9] in M. argentinum sp. nov. vs. internal primary branch [64.4-102.9], internal base + secondary branch [32.9-56.8], internal spur [11.1-23.2] in M. zsalakoae).

\section{Milnesium beatae sp. nov.}

http://www.tardigrada.net/register/0016.htm.

Material examined: Seven females, all from Nahuel Huapi National Park, Río Negro, Argentina, moss sample from rocks, coll. Łukasz Kaczmarek.

Type material: Holotype and six paratypes in the sample III.

\section{Diagnosis}

Adults (Figure 1b) (measurements in micrometres, pt ratios and statistics in Table 2): The body rose before fixation and transparent afterwards, eyes present. Cuticle sculptured with pseudopores (0.3 to 0.6 ) not arranged in bands, sparsely distributed and not forming reticular design (Figure 2d). Six peribuccal papillae and six peribuccal lamellae around the mouth opening present. Two cephalic papillae positioned laterally. Peribuccal and cephalic papillae similar in length.

Buccal apparatus of the Milnesium type (Figure 2c). Buccal tube wide and short (standard width on average $62 \%$ of its length) and funnel-shaped, wider anteriorly (posterior diameter on average $72 \%$ of the anterior diameter). Pharyngeal bulb elongated, pear-shaped and without placoids or septulum.

Claws of the Milnesium type, slender (Figure 3d,e). Primary branches on all legs with small, but distinct accessory points detaching from the branch at its greatest curvature (Figure 3d,e). Secondary branches with rounded basal thickenings (Figure 3d,e). All secondary branches on all legs with three points (claw configuration: [3-3]-[3-3]). Single, long transverse, cuticular bars under claws I-III present (Figure 3d).

Eggs: Oval, smooth and deposited in exuvium as in all other known Milnesium species.

Males not observed.

Locus typicus: Argentina, 41 $1^{\circ} 12^{\prime} \mathrm{S}, 71^{\circ} 50^{\prime} \mathrm{W}$, ca. 1,000 m asl., Río Negro, Nahuel Huapi National Park.

Etymology: This species is named after first author's secondary school Biology teacher - Mrs. Beata Ostasiewicz.

Type depositories: The holotype and all paratypes are deposited in the Department of Animal Taxonomy and Ecology, Adam Mickiewicz University in Poznań, Umultowska 89, Poznań, Poland.

\section{Differential diagnosis}

By having a sculptured dorsal cuticle, M. beatae sp. nov. belongs to the granulatum group within the genus (Michalczyk et al. 2012a,b). This new species with three points on the secondary branches of all claws [3-3]-[3-3] and very short and wide buccal tube is most similar to M. bohleberi, M. brachyungue Binda and Pilato 1990 and M. eurystomum, but it differs from the following:

1. M. bohleberi by having sculptured dorsal cuticle and lower $p t$ of peribuccal papillae length ([18.0-23.6] in M. beatae sp. nov. vs. [27.2-32.3] in M. bohleberi).

2. M. brachyungue by having sculptured dorsal cuticle, stylet supports inserted in more cephalic position ([63.8-66.7] in M. beatae sp. nov. vs. [69.4] in $M$. brachyungue (in specimen 729.0 in length)) and lower $p t$ of claws I to IV (see Table 2 and Table one in Binda and Pilato (1990) for the exact differences in dimensions of claws).

3. M. eurystomum by having sculptured dorsal cuticle, stylet supports inserted in more caudal position ([63.8-66.7] in M. beatae sp. nov. vs. [60.0-60.3] in $M$. eurystomum) and slightly different $p t$ of claws I to IV (see Table 2 and Table two in Michalczyk et al. (2012a) for the exact differences in dimensions of claws).

Besides the abovementioned the most similar species, $M$. beatae sp. nov. is similar to other species of the genus Milnesium with the claw configuration [3-3]-[3-3] (M. alabamae, M. antarcticum, $M$. asiaticum, $M$. barbadosense, M. eurystomum, M. granulatum, M. longiungue and $M$. zsalakoae) or with a sculptured cuticle (M. beasleyi, M. katarzynae, M. krzysztofi and $M$. reticulatum). 
This new species differs from the following:

4. M. alabamae by different dorsal sculpture (pseudopores not arranged in bands, sparsely distributed and not forming a reticular design in $M$. beatae sp. nov. vs. pseudopores arranged in bands (especially in caudal region), densely distributed and forming a reticular design in $M$. alabamae), presence of accessory points on main branches of claws, presence of eyes and lower $p t$ of standard width of buccal tube ([58.1-65.6] in $M$. beatae sp. nov. vs. [29.5-44.0] in M. alabamae).

5. M. antarcticum by having sculptured dorsal cuticle, higher $p t$ of standard width of buccal tube ([58.1-65.6] in M. beatae sp. nov. vs. [35.4-43.9] in $M$. antarcticum) and stylet supports inserted in more cephalic position ([63.8-66.7] in $M$. beatae sp. nov. vs. [70.0-73.7] in $M$. antarcticum).

6. $M$. argentinum sp. nov. by stylet supports inserted in more cephalic position ([63.8-66.7] in M. beatae sp. nov. vs. [70.0-73.7] in M. argentinum sp. nov.), lower $p t$ of width of buccal tube ([70.3-78.9], [58.1-65.6], [49.4-56.5] anterior, standard and posterior, respectively, in $M$. beatae sp. nov. vs. [30.3-39.8], [24.2-32.3], [23.1-33.6] anterior, standard and posterior, respectively, in $M$. argentinum sp. nov. and longer claws I to IV (see Tables 1 and 2 for the exact differences in dimensions of claws).

7. M. asiaticum by having sculptured dorsal cuticle, lower $p t$ of standard width of buccal tube ([58.1-65.6] in M. beatae sp. nov. vs. [30.0-41.6] in M. asiaticum) and slightly different $p t$ of claws I to IV (see Table 2 and Table four in Tumanov (2006) for the exact differences in dimensions of claws).

8. M. barbadosense by having sculptured dorsal cuticle, presence of eyes and lower $p t$ of standard width of buccal tube ([58.1-65.6] in M. beatae sp. nov. vs. [27.2-49.7] in M. barbadosense).

9. $M$. beasleyi by different claw configuration ([3-3]-[3-3] in M. beatae sp. nov. vs. [2-3]-[3-2] in $M$. beasleyi), presence of rounded basal thickenings under secondary branches of claws, higher $p t$ of width of buccal tube ([70.3-78.9], [58.1-65.6], [49.4-56.5] anterior, standard and posterior, respectively, in $M$. beatae sp. nov. vs. [35.3-41.8], [31.2-39.8], [29.6-33.2] anterior, standard and posterior, respectively, in $M$. beaslei,]) and slightly smaller claws I to IV (see Table 2 and Table one in Kaczmarek et al. (2012a, b) for the exact differences in dimensions of claws).

10. $M$. berladnicorum by different claw configuration ([3-3]-[3-3] in M. beatae sp. nov vs. [2-3]-[2-2] in M. berladnicorum), higher $p t$ of width of buccal tube ([70.3-78.9], [58.1-65.6], [49.4-56.5] anterior, standard and posterior, respectively, in $M$. beatae sp. nov. vs. [35.0-47.1], [30.6-38.9], [27.7-36.0] anterior, standard and posterior, respectively, in $M$. berladnicorum]) and smaller claws I to IV (see Table 2 and Table one in Ciobanu et al. (2014b) for exact differences in dimensions of claws).

11. M. granulatum by different dorsal sculpture (pseudopores not arranged in bands, sparsely distributed and not forming a reticular design in $M$. beatae sp. nov. vs. pseudopores densely distributed and forming a reticular design in M. granulatum), higher $p t$ of width of buccal tube ([70.3-78.9], [58.1-65.6], [49.4-56.5] anterior, standard and posterior, respectively, in $M$. beatae sp. nov. vs. [46,3], [39.0], [40.1] anterior, standard and posterior, respectively, in $M$. granulatum (in specimen 338.3 in length)) and slightly larger claws I to IV (see Table 2 and Table two in Kaczmarek et al. (2012a, b) for the exact differences in dimensions of claws).

12. M. katarzynae by a different claw configuration ([3-3]-[3-3] in M. beatae sp. nov. vs. [2-2]-[2-2] in M. katarzynae), different dorsal sculpture (pseudopores not arranged in bands, sparsely distributed and not forming a reticular design in $M$. beatae sp. nov. vs. pseudopores densely distributed and forming a reticular design in M. katarzynae), presence of eyes, higher $p t$ of standard width of buccal tube ([58.1-65.6] in M. beatae sp. nov. vs. [21.7-26.6] in M. katarzynae and stylet supports inserted in more cephalic position ([63.8-66.7] in $M$. beatae sp. nov. vs. [73.3-78.3] in M. katarzynae).

13. M. krzysztofi by different claw configuration ([3-3]-[3-3] in M. beatae sp. nov. vs. [2-3]-[3-2] in M. krzysztofi), different dorsal sculpture (pseudopores not arranged in bands, sparsely distributed and not forming a reticular design in $M$. beatae sp. nov. vs. pseudopores densely distributed and forming a reticular design in $M$. krzysztofi), presence of eyes, higher $p t$ of buccal tube standard width ([58.1-65.6] in $M$. beatae sp. nov. vs. [33.1-38.4] in M. krzysztofi) and smaller claws I to IV (see Table 2 and Table one in Kaczmarek and Michalczyk (2007) for the exact differences in dimensions of claws).

14. M. longiungue by having sculptured dorsal cuticle, presence of accessory points on the main branches of claws, slightly higher $p t$ of standard width of buccal tube ([58.1-65.6] in M. beatae sp. nov. vs. [33.8-59.1] in M. longiungue) and smaller claws I to IV (see Table 2 and Table six in Tumanov (2006) for the exact differences in dimensions of claws).

15. $M$. reticulatum by different claw configuration ([3-3]-[3-3] in M. beatae sp. nov. vs. [2-3]-[3-2] in $M$. reticulatum), different dorsal sculpture 
(pseudopores not arranged in bands, sparsely distributed and not forming a reticular design in $M$. beatae sp. nov. vs. pseudopores arranged in nine sculptured bands, forming a reticular design in $M$. reticulatum), absence of cuticular gibbosities, having six peribuccal lamellae (four in $M$. reticulatum), stylet supports inserted in more cephalic position ([63.8-66.7] in M. beatae sp. nov. vs. [68.5-69.8] in M. reticulatum), higher $p t$ of standard width of buccal tube ([58.1-65.6] in $M$. beatae sp. nov. vs. [30.4-37.4] in M. reticulatum) and different measurements of claws I to IV (see Table 2 and Table two in Pilato et al. (2002) for the exact differences in dimensions of claws).

16. M. zsalakoae by having sculptured dorsal cuticle, presence of accessory points on main branches of claws, higher $p t$ of buccal tube standard width ([58.1-65.6] in M. beatae sp. nov. vs. [36.8-41.9] in M. zsalakoae), stylet supports inserted in more cephalic position ([63.8-66.7] in M. beatae sp. nov. vs. [68.2-71.1] in M. zsalakoae) and higher $p t$ of internal claws I to IV (see Table 2 and the description of M. zsalakoae in Meyer and Hinton (2010) for the exact differences in dimensions of claws).

\section{Milnesium brachyungue Binda and Pilato, 1990}

Terra typica: Chile (South America).

Localities and number of specimens in present studies: Five females in sample VI.

Remarks: Until now this species was considered as an endemic of Chile (Binda and Pilato 1990) (Table 3). This is a second report of the species and a new record for Argentina. Milnesium brachyungue is relatively similar to $M$. tardigradum and it is possible that the specimens of $M$. tardigradum sensu stricto reported from South America (especially from southern regions of Chile or Argentina) in the past belong rather to $M$. brachyungue, but this hypothesis needs to be confirmed. We strongly suggest that all specimens reported as $M$. tardigradum s. s. from this region should be re-examined and determined based on the modern taxonomic characters (see also Michalczyk et al. 2012a,b).

\section{Milnesium eurystomum Maucci, 1991}

Terra typica: Denmark (Arctic, Greenland).

Localities and number of specimens in present studies: None.

Remarks: Species reported from Argentina, Chile, Mongolia (probably), Spain, Svalbard, USA and locus typicus on Greenland (Maucci 1991, 1996; Kaczmarek and Michalczyk 2006; Guil 2008; Kaczmarek et al. 2012a, b; Land et al. 2012; Johansson et al. 2013) (Table 3). This species is characterized by a very wide and relatively short buccal tube, claw configuration [3-3]-[3-3] and smooth cuticle. Recently, a similar species (with a short and wide buccal tube), $M$. bohleberi, was described from North America (USA, North Carolina and Tennessee) (Bartels et al. 2014). In this situation, we suggest that the examples, especially from South and North America, should be re-examined (see also Michalczyk et al. 2012a,b). In Mongolia this species was reported as M. cf. eurystomum Maucci 1991 (Kaczmarek and Michalczyk 2006) and its presence in this region needs confirmation.

\section{Minesium granulatum Ramazzotti, 1962}

Terra typica: Chile (South America).

Localities and number of specimens in present studies: Two females in sample II.

Remarks: Species reported from Argentina, Chile, Colombia, Italy, Romania and USA (Ramazzotti 1962; Michalczyk et al. 2012a,b; Ciobanu et al. 2014a; Melo et al. 2014) (Table 3). As mentioned by Bartels et al. (2014), such wide and discontinuous geographic distribution can suggest a complex of cryptic species, but testing this hypothesis requires molecular data which are not yet available. We suggest that at least the examples

Table 3 Distribution of the species of genus Milnesium in South America

\begin{tabular}{|c|c|c|c|c|c|c|c|c|c|c|}
\hline \multirow[t]{2}{*}{ Species } & \multicolumn{10}{|l|}{ Country } \\
\hline & Argentina & Bolivia & Brazil & Chile & Colombia & Ecuador & Paraguay & Peru & Uruguay & Venezuela \\
\hline M. argentinum & $x$ & & & & & & & & & \\
\hline M. beatae & $x$ & & & & & & & & & \\
\hline M. brachyungue & $x$ & & & $x$ & & & & & & \\
\hline M. eurystomum & $x$ & & & $x$ & & & & & & \\
\hline M. granulatum & $x$ & & & $x$ & $x$ & & & & & \\
\hline M. katarzynae & & & & & $x$ & & & & & \\
\hline M. krzysztofi & & & & & $x$ & & & $x$ & & \\
\hline M. t. tardigradum & $x$ & $x$ & $x$ & $x$ & $x$ & $x$ & $x$ & $x$ & $x$ & $x$ \\
\hline M. t. trispinosa & & & $x$ & $x$ & & & & & & \\
\hline
\end{tabular}


from Europe should be carefully re-examined (see also Michalczyk et al. 2012a,b).

\section{Milnesium katarzynae Kaczmarek et al., 2004 \\ Terra typica: China (Asia). \\ Localities and number of specimens in present studies: None. \\ Remarks: Until now, this species was known only from China (locus typicus) (Kaczmarek et al. 2004), Costa Rica (Kaczmarek et al. 2014a), Colombia (Melo et al. 2014) and Taiwan (Yin and Li 2011) (Table 3). Such distribution may suggest a pantropical distribution of this species.}

\section{Milnesium krzysztofi Kaczmarek and Michalczyk 2007}

Terra typica: Costa Rica (Central America).

Localities and number of specimens in present studies: None.

Remarks: Until now, this species was known only from Costa Rica (locus typicus) (Kaczmarek and Michalczyk 2007), Colombia (Lisi et al. 2014; Melo et al. 2014) and Peru (Kaczmarek et al. 2014a,b) (Table 3). Such distribution may suggest a neotropical distribution of this species.

\section{Milnesium tardigradum tardigradum Doyère 1840}

Terra typica: Chile (South America).

Localities and number of specimens in present studies: None.

Remarks: This species has been reported from many localities in South America (McInnes 1994, see also the 'Discussion' section and Table 3). For over a century, Milnesium was considered to be a monotypic, highly cosmopolitan genus. However, currently there are more than 20 species within the genus and it is very likely that the zoogeographic range of $M$. tardigradum s. s. is limited to the Palaearctic (Michalczyk et al. 2012a,b). This means that all South American reports for M. tardigradum that occurred prior to the re-description of $M$. tardigradum s. s. (Michalczyk et al. 2012a,b) should be considered dubious and need a re-examination based on the modern taxonomy of the genus Milnesium. In other words, currently, there is no evidence that $M$. tardigradum s. s. inhabits South America; thus, its records may represent a number of different Milnesium taxa (Michalczyk et al. 2012a,b, see also remarks on other Milnesium species, especially on $M$. brachyungue).

\section{Milnesium tardigradum trispinosa Rahm 1932 [T]}

Terra typica: Chile (South America).

Localities and number of specimens in present studies: None.

Remarks: A subspecies reported from single localities in Chile and Brazil (Table 3). This unique subspecies is characterized by the presence of short spines on dorsal cuticle. It should be probably promoted to the species level, but the re-description based on type material (or based on specimens collected in the type locality) is necessary (Michalczyk et al. 2012a,b).

\section{Discussion}

\section{Distribution}

Milnesium species have been recorded from many localities throughout the world (Michalczyk et al. 2012a,b) and one of them, M. swolenskyi Bertolani and Grimaldi 2000, is also known from Cretaceous amber collected in the USA (Bertolani and Grimaldi 2000). For a long time, $M$. tardigradum Doyère 1840 was the only recognised species in the genus and it has been considered as an extremely cosmopolitan taxon (e.g. Ramazzotti and Maucci 1983). In the past, even morphologically very different specimens were still considered as only different forms or subspecies of the type M. tardigradum (e.g. Rahm 1932; Ramazzotti 1962; Sudzuki 1964; Horning et al. 1978; Nelson and Horning 1979; Dastych 1984). Interestingly, even that Nederström 1919 described a new Milnesium species, Milnesium quadrifidum, this new taxon was later recognised only as a specific form of $M$. tardigradum (Szymańska 1994 according to Marcus 1936) and finally excluded from the list of tardigrade taxa at all. It was not until 1990 that Binda and Pilato described a new Milnesium species, M. brachyungue, from Tierra del Fuego. Later, new species were described only occasionally mainly due to the lack of a clear diagnosis of the nominal species $M$. tardigradum s. s. (Maucci 1991; Bertolani and Grimaldi 2000; Pilato et al. 2002; Yang 2003; Kaczmarek et al. 2004). In 2006, Tumanov published the first partial revision of the genus Milnesium and described five new species. Since this time, many new species have been described and now 25 taxa (including the two new species described in this paper) are known in the genus (Degma et al. 20092014). The majority of the newly described species are known only from their type localities and Michalczyk et al. $(2012 \mathrm{a}, \mathrm{b})$ hypothesised that M. tardigradum s. s. is not a cosmopolitan species, but previous reports from various localities should be re-examined in light of new taxonomic characters because they probably belong to different species (see also Meyer 2013). Based on the present data, most of the species from the genus Milnesium have truly restricted geographic ranges, as was also shown in other tardigrade genera (e.g. Pilato and Binda 2001).

As of now, nine Milnesium taxa are known from South America (including two new species reported in this paper) (Table 3). These are $M$. argentinum sp. nov. and $M$. beatae sp. nov. (currently restricted to Argentina), $M$. brachyungue (known from Argentina and Chile), $M$. eurystomum (known from Argentina, Chile, Greenland, Mongolia (probably), Spain, Svalbard and USA), $M$. 
granulatum (known from Argentina, Chile, Colombia, Italy, Romania and USA), M. katarzynae (known from China, Colombia, Costa Rica and Taiwan), M. krzysztofi (known from Colombia, Costa Rica and Peru), M. tardigradum sensu lato (known from Argentina, Bolivia, Brazil, Chile, Colombia, Ecuador, Paraguay, Peru, Uruguay and Venezuela) and M. t. trispinosa (known from Chile and Brazil) (Richters (1911a); Murray and Wailes (1913); Heinis (1914); Rahm (1931, 1932); de Barros (1943); (du Bois-Reymond 1944); Ramazzotti (1957, 1962, 1964); Iharos (1963); Mihelčič (1967, 1972) Rossi and Claps (1980, 1989, 1991); Claps and Rossi (1981, 1984, 1988, 1997); Maucci (1988); Binda and Pilato (1990), Maucci (1991, 1996); Séméria (1993); McInnes (1994); Jerez Jaimes and Narváez Parra (2001); Nickel et al. (2001); Pilato et al.(2003); Kaczmarek et al. (2004, 2012a,b); Kaczmarek and Michalczyk (2006, 2007); Moly de Peluffo et al.(2006); Peluffo et al.(2007); Guil (2008); Rossi et al.(2009); Kaczmarek et al. (2012a,b), Land et al. (2012), Michalczyk et al. (2012a,b), Johansson et al. (2013); Ciobanu et al. (2014a); Lisi et al. (2014); Melo et al. (2014)).

As shown above, only $M$. tardigradum s. 1 . has a wide distribution in South America, however the presence of this species in this region is doubtful and needs confirmation. The present study seems to confirm this hypothesis, because although four Milnesium species were found in the samples studied, none of them was recognised as the nominal $M$. tardigradum. This also confirms the hypothesis proposed by Michalczyk et al. (2012a,b) that M. tardigradum have rather a narrower geographic range (restricted to Holarctic or Palearctic), although more extensive studies (molecular) are necessary in other regions of South America.

Similar to M. tardigradum s.s., other species of the genus Milnesium also have restricted geographic ranges (e.g. M. alabamae, M. almatyense Tumanov 2006, M. antarcticum, M. barbadosense, M. beasleyi, M. jacobi Meyer and Hinton 2010, M. brachyungue, M. dujiangensis Yang 2003, M. lagniappe Meyer et al. 2013, M. longiungue, M. reductum Tumanov 2006, M. reticulatum, $M$. tetralamellatum Pilato and Binda 1991 and M. zsalakoae), which seems to support the hypothesis that none of the Milnesium species is cosmopolitan (Bartels et al. 2014). However, as was also shown by Bartels et al. (2014), some of the Milnesium species have rather wide and discontinuous geographic ranges ( $M$. asiaticum, $M$. eurystomum, $M$. granulatum, $M$. katarzynae and $M$. krzysztofi), which can suggest the presence of cryptic species complexes or a specific distribution of some of the taxa (e.g. pantropical for M. katarzynae or neotropical for $M$. krzysztofi). In this situation, only detailed morphological and molecular studies could shed light on this issue.

\section{Remarks on feeding behaviour}

Very little is known about food preferences in tardigrades, although, many different types of food sources have been reported, i.e. plant cell fluids, algae, bacteria, protozoa and small invertebrates like nematodes, rotifers and other tardigrades (for the review, see Schill et al. 2011). Previous studies have focused on the following: a) the rate of consumption, e.g. in the carnivorous Paramacrobiotus richtersi (Murray, 1911), b) predator-prey interactions ( $P$. richtersi vs. nematodes), c) population dynamics and food availability in the herbivorous tardigrade Apodibius confusus Dastych, 1983, d) tardigrade food preferences in the herbivorous Echiniscus granulatus (Doyère, 1840), Macrobiotus sapiens Binda and Pilato, 1984, M. persimilis Binda and Pilato, 1972, Richtersius coronifer (Richters, 1903) and the carnivorous $P$. richters $i$, e) life histories of some species and f) different aspects of tardigrade histology (e.g. Suzuki 2003; Hohberg and Traunspurger 2005, 2009; Poprawa 2005, 2011; Hohberg 2006; Horikawa et al. 2008; Hohberg et al. 2011; Lemloh et al. 2011; Schill et al. 2011; Schill 2013), give us some incomplete information on tardigrade feeding behaviour.

The species in the genus Milnesium are relatively large (occasionally more than $2 \mathrm{~mm}$ but most often between 0.5 to $1.0 \mathrm{~mm}$ ) and inhabit mainly limno-terrestrial habitats (Guil 2008). Their buccal tube is wide, relatively short, connected with a large pharynx without placoids and associated with large buccal lamellae on a wide mouth ring, which is in agreement with the definition of the 'carnivore type' of buccal apparatus proposed by Guidetti et al. (2012). All Milnesium species are considered carnivorous and feed on other small invertebrates like rotifers, nematodes, tardigrades and sometimes also on amoebas (e.g. Kinchin 1990; Suzuki 2003; Nelson et al. 2010; Miller and Williams 2012).

In contrast to other predatory tardigrades from genera such as Bertolanius Özdikmen, 2008, Macrobiotus C.A.S. Schultze, 1834 or Paramacrobiotus Guidetti et al., 2009, Milnesium species suck the entire prey into the gut rather than only single cells or body fluids (McInnes et al. 2001). However, also species from the genus Bertolanius (i.e. Bertolanius weglarskae (Dastych 1972)) can suck in entire prey (see Figure 1a in Guidetti and Bertolani 2001). McInnes et al. (2001) analysed the diet of subAntarctic specimens of $M$. cf. tardigradum. They found in the guts of $M$. cf. tardigradum not only remnants but also entire specimens of three different species of Rotifera (Bdelloidea: Adineta sp., Philodina spp. and Monogononta: Dicranophorus sp.), unidentified species of Nematoda and two species of Tardigrada (Diphascon sp. and Calohypsibius cf. ornatus). Miller and Williams (2012) reported a Greenland tardigrade M. eurystomum feeding on shelled (testate amoebae) (similar to Euglypha). 
Additionally, the same authors suggested that $M$. eurystomum has the ability to properly orient their prey, so that the amoeba can be extracted by the sucking action and later the empty shell can be expelled. However, specific differences in the feeding behaviour in connection with the structure of buccal apparatus in different Milnesium species have never been discussed.

In the present research, a total of 25 adult specimens of two new Milnesium species: M. argentinum (18 specimens) and M. beatae (7 specimens) were studied. Both species were found in the same region of Nahuel Huapi National Park (Río Negro Province, Argentina) in a few moss samples. Five specimens (two specimens of $M$. argentinum sp. nov. and three specimens of $M$. beatae sp. nov.) were found with the remnants of food (rotifer mastaxes and tardigrade buccal apparatuses and claws) in their guts. Both species were found in the moss samples (sometimes also together in the same piece of moss) that also contained rotifers, nematodes and other tardigrades (Diphascon chilenense Plate, 1888, Echiniscus bigranulatus Richters 1907, Hebesuncus mollispinus Pilato et al. 2012, Macrobiotus cf. andinus, M. harmsworthi group, M. kazmierskii Kaczmarek and Michalczyk 2009, M. patagonicus Maucci 1988, M. szeptyckii Kaczmarek and Michalczyk 2009, Mopsechiniscus granulosus Mihelčič 1967). Both new Milnesium species were able to choose from the same type of prey, because the prey were similar in every sample.

The main morphological differences between $M$. argentinum sp. nov. and M. beatae sp. nov. are visible in the structure of buccal tube. Milnesium argentinum sp. nov. has a relatively long and narrow buccal tube while $M$. beatae sp. nov. has a relatively short and wide buccal tube (in the specimens of similar lengths, see Tables 1 and 2). Based on gut contents, both species seem also to have a different diet: the two specimens of $M$. argentinum sp. nov. fed on undefined species of rotifers (Figure 3c), while the three specimens of $M$. beatae sp. nov. fed on other tardigrades (exclusively M. szeptyckii) (Figure 3f). In general, specimens of M. szeptyckii are larger (360 to $650 \mu \mathrm{m}$ ) and more bulky (a wider buccal tube is probably necessary to swallow them) than typical rotifers which are shorter (100 to $500 \mu \mathrm{m}$ ) and more slender (a narrower buccal tube is sufficient to swallow them). Although the numbers are small, these data suggest that the buccal tube width may affect the type of prey consumed. However, it should be also noted that McInnes et al. (2001) showed that both tardigrades and rotifers were found in the gut of the same specimen of $M$. cf. tardigradum. But, according the photo (Figure 1a in McInnes et al. 2001), the Milnesium species studied by McInnes et al. (2001) had rather long and narrow buccal tube (similarly to $M$. argentinum sp. nov.) and fed on rather small and slender prey (rotifers, nematodes and small and slender tardigrades from the genera
Diphascon Plate, 1888 and Calohypsibius Thulin 1928), which is in agreement with the observations made in the present research.

Although neither McInnes et al. (2001) observations nor the present research provided a definitive answer whether the buccal tube width has a crucial role in the choice of different types of prey, these studies are the basis for further, more comprehensive studies.

Such studies are necessary also to understand the evolution of buccal apparatuses in other genera of the family Milnesiidae (Bergtrollus Dastych 2011, Limmenius Horning, Schuster and Grigarick, 1978 and Milnesioides Claxton 1999). However, we know almost nothing about feeding behaviour and prey choice of the members of these monophyletic genera. Only Claxton (1999) mentioned some specimens of $M$. exsertum that had remnants of rotifers in their guts. This is a very interesting observation, because this species has a very long and narrow buccal tube, similarly to the 'rotifer-feeding' $M$. argentinum sp. nov.

Based on the available data, it can be initially hypothesised that the species from the family Milnesiidae with long and narrow buccal tubes (e.g. M. argentinum sp. nov., Antarctic $M$. cf. tardigradum or $M$. exsertum) choose smaller and more slender prey (rotifers or small slender tardigrades from genera Diphascon or Calohypsibius) in contrast to the species with relatively short and wide buccal tubes (e.g. M. beatae sp. nov. or $M$. eurystomum) which choose more robust and larger or armoured prey (large and robust tardigrades from the genus Macrobiotus or testate amoebae). Certainly, such conclusions based only on the 'post-mortem' studied specimens give us only very limited knowledge on the food that had been eaten just before death (preservation) of the animal. Such information needs confirmation in further, more detailed experimental studies with molecular methods (e.g. Schill et al. 2011) or based directly on the observations in cultured animals (e.g. Suzuki 2003).

\section{Conclusions}

Milnesium argentinum and $M$. beatae are new taxa for science. As of now, nine Milnesium taxa are known from South America (including the two new species and two newly recorded taxa for Argentina, reported in this paper). The presence of $M$. tardigradum s. s. in South America needs confirmation and for now it should be considered as dubious. It is probable that width of buccal tube may limit a prey size and play an important role in the feeding behaviour in the family Milnesiidae. Studies on the feeding behaviour in tardigrades are in initial phase and definitive conclusions are not possible at this moment. 


\section{Competing interests}

The authors declare that they have no competing interests.

\section{Authors' contributions}

MR examined and analysed the material, identified and described the species, made the measurements, figures and tables and drafted the manuscript. MO made the measurements and tables. $Ł K$ collected part of the material, invented the research conception, analysed the examined material, identified and described the species, corrected tables and drafted the manuscript. All authors read and approved the final manuscript.

\section{Acknowledgements}

The authors want to thank Prof. Diane Nelson of East Tennessee State University for very valuable comments to the manuscript and help in improving of the English. This work was partially supported by the Polish Ministry of Science and Higher Education via the 'luventus Plus' programme (grant: IP2010 015570, Invertebrate biodiversity in temporary ponds of Costa Rica - verification of the 'Great American Biotic Interchange' hypothesis) and by the Prometeo Project of the Secretariat for Higher Education, Science, Technology and Innovation of the Republic of Ecuador. Studies have been conducted in the framework of activities of BARg (Biodiversity and Astrobiology Research group).

\section{Received: 15 August 2014 Accepted: 10 December 2014}

\section{Published online: 14 January 2015}

\section{References}

Bartels PJ, Nelson DR, Kaczmarek $Ł$, Michalczyk $Ł$ (2014) The genus Milnesium (Tardigrada: Eutardigrada: Milnesiidae) in the Great Smoky Mountains National Park (North Carolina and Tennessee, USA), with the description of Milnesium bohleberi sp. nov. Zootaxa 3826(2):356-368

Bertolani R, Grimaldi D (2000) A new eutardigrade (Tardigrada: Milnesiidae) in amber from the Upper Cretaceous (Turonian) of New Jersey. In: Grimaldi D (ed) Studies on fossils in amber, with particular reference to the Cretaceous of New Jersey. Backhuys Publishers, Leiden The Netherlands, pp 103-110

Binda MG, Pilato G (1972) Tardigradi muscicoli di Sicilia (IV Nota). Boll Accad Gioenia Sci Nat Catania 11:47-60

Binda MG, Pilato G (1984) Macrobiotus sapiens, nuova specie di eutardigrado di Sicilia. Animalia 11:85-90

Binda MG, Pilato G (1990) Tardigradi di Terra del Fuoco e Magallanes, I. Milnesium brachyungue, nuova specie di tardigrado Milnesiidae. Animalia 17:105-110

Binda MG, Pilato G (1994a) Echiniscus peruvianus, nuova specie di eterotardigrado del Sudamerica. Animalia 21:57-62

Binda MG, Pilato G (1994b) Dactylobiotus caldarellai, nuova specie di eutardigrado della Terra del Fuoco. Animalia 21:87-91

Binda MG, Pilato G (1999a) Dactylobiotus lombardoi sp. n. (Eutardigrada: Macrobiotidae) from Tierra del Fuego, with a Key to the Dactylobiotus-species. Zool Anz 238:147-155

Binda MG, Pilato G (1999b) Macrobiotus erminiae, new species of eutardigrade from southern Patagonia and Tierra del Fuego. Entomol Mit Zool Mus Hamb 13:151-158

Ciobanu DA, Moglan I, Zawierucha K, Kaczmarek $Ł$ (2014a) New records of terrestrial tardigrades (Tardigrada) from Ceahlău National Park with zoogeographical and taxonomical remarks on Romanian water bears. North-West J Zool 10:art.140301

Ciobanu DA, Zawierucha K, Moglan I, Kaczmarek $Ł$ (2014b) Milnesium berladnicorum sp. n. (Eutardigrada, Apochela, Milnesiidae), a new species of water bear from Romania. ZooKeys 429:1-11

Claps MC, Rossi GC (1981) Contribucion al conocimiento de los tardigrados de Argentina. II Rev Soc Entomol Arg 40(1-4):107-114

Claps MC, Rossi GC (1984) Contribucion al conocimiento de los tardigrados de Argentina. IV. Acta Zool Lilloana 38:45-50

Claps MC, Rossi GC (1988) Contribucion al conocimiento de los tardigrados de Argentina. VI Iheringia 67:3-11

Claps MC, Rossi GC (1997) Tardigrados de Uruguay, com descripcion de dos nuevas especies (Echiniscidae, Macrobiotidae). Iheringia Sér Zool 83:17-22

Claxton SK (1998) A revision of the genus Minibiotus (Tardigrada: Macrobiotidae) with descriptions of eleven new species from Australia. Rec Aust Mus 50:125-160

Claxton SK (1999) Milnesioides exsertum gen. n. sp. n., a new tardigrade from Australia (Tardigrada: Milnesiidae). Zool Anz 238:183-190
Dastych H (1980) Niesporczaki (Tardigrada) Tatrzańskiego Parku Narodowego. Monogr Faun Pol PWN Krakow 9:1-232

Dastych H (1984) The Tardigrada from Antartica with description of several new species. Acta Zool Cracov 27:377-436

Dastych H (1999a) Redescription of the Sub-Antarctic tardigrade Mopsechiniscus imberbis (Richters, 1908) (Tardigrada). Mitt Hamb Zool Mus Inst 96:21-35

Dastych H (1999b) A new species of the genus Mopsechiniscus Du Bois-Reymond Marcus, 1944 (Tardigrada) from the Venezuelan Andes. A Biol Benrod 10:91-101

Dastych H (2000) Redescription of the Neotropical tardigrade Mopsechiniscus granulatus Mihelcic, 1967 (Tardigrada). Mitt Hamb Zool Mus Inst 97:45-57

Dastych H, Mclnnes S, Claxton SK (1998) Oreella mollis Murray, 1910 (Tardigrada): a redescription and revision of Oreella. Mitt Hamb Zool Mus Inst 95:89-113

De Barros R (1943) Tardigrados de Estado de Sao Paulo, Brasil. III. Gêneros Hypsibius, Itaquascon e Milnesium. Rev Brasil Biol 3:1-10

Degma P, Guidetti R (2007) Notes to the current checklist of Tardigrada. Zootaxa 1579:41-53

Degma P, Michalczyk $Ł$, Kaczmarek $Ł$ (2008) Macrobiotus derkai, a new species of Tardigrada (Eutardigrada, Macrobiotidae, huziori group) from the Colombian Andes (South America). Zootaxa 1731:1-23

Degma P, Bertolani R, Guidetti R (2014) Actual checklist of Tardigrada species (2009-2014, Ver. 26:10-07-2014). http://www.tardigrada.modena.unimo.it/ miscellanea/Actual\%20checklist\%20of\%20Tardigrada.pdf

Doyère M (1840) Memoire sur les tardigrades. Ann Sci Nat Zool Paris Ser 2 (14):269-362

du Bois-Reymond ME (1944) Sobre tardígrados brasileiros. Comun Zool Mus Hist Nat Monte 1(13):1-19

Edwards TL (2008) Argentina: a global studies handbook. ABC-CLIO, Santa Barbara, CA, USA

Guidetti R, Bertolani R (2001) The tardigrades of Emilia (Italy). III. Piane di Mocogno (Northern Apennines). Zool Anz 240:377-383

Guidetti R, Bertolani R (2005) Tardigrade taxonomy: an updated check list of the taxa and a list of characters for their identification. Zootaxa 845:1-46

Guidetti R, Schill RO, Bertolani R, Dandekar T, Wolf M (2009) New molecular data for tardigrade phylogeny, with erection of Paramacrobiotus gen. n. J Zool Syst Evol Res 47:315-321

Guidetti R, Altiero T, Marchioro T, Sarzi Amade L, Avdonina AM, Bertolani R, Rebecchi $L$ (2012) Form and function of the feeding apparatus in Eutardigrada (Tardigrada). Zoomorphol 131(2):127-148

Guidetti R, Peluffo JR, Rocha AM, Cesari M, Moly de Peluffo MC (2013) The morphological and molecular analyses of a new South American urban tardigrade offer new insights on the biological meaning of the Macrobiotus hufelandi group of species (Tardigrada: Macrobiotidae). J Nat Hist 47(37-38):2409-2426

Guil N (2008) New records and within-species variability of Iberian tardigrades (Tardigrada), with comments on the species from the Echiniscus-blumi-canadensis series. Zootaxa 1757:1-30

Heinis F (1914) Die Moosfauna Columbiens. Mém Soc Sci Nat Neu 5:713-724

Hinton JG, Meyer HA, Soileau BN, Dupuid AP (2013) Tardigrada of the Caribbean island of Dominica (West Indies). J Limnol 72(S1):108-112

Hohberg K (2006) Tardigrade species composition in young soils and some aspects on life history of Macrobiotus richtersi J. Murray, 1911. Pedobiologia $50: 267-274$

Hohberg K, Traunspurger W (2005) Predator-prey interaction in soil food web: functional response, size-dependent foraging efficiency, and the influence of soil texture. Biol Fert 41(6):419-427

Hohberg K, Traunspurger W (2009) Foraging theory and partial consumption in a tardigrade-nematode system. Behav Ecol 20(4):884-890

Hohberg K, Russell DJ, Elmer M (2011) Mass occurrence of algal-feeding tardigrade Apodibius confusus, in the young soils of a post-mining site. J Zool Syst Evol Res 49(S1):62-65

Holt BG, Lessard JP, Borregaard MK, Fritz SA, Araújo MB, Dimitrov D, Fabre PH, Graham CH, Graves GR, Jønsson KA, Bravo DN, Wang Z, Whittaker RJ, Fjeldså J, Rahbek C (2013) An update of Wallace's Zoogeographic Regions of the World. Science 339(6115):74-78

Horikawa D, Kunieda T, Abe W, Watanabe M, Nakahara Y, Yukuhiro F, Sakashita T, Hamada N, Wada S, Funayama T, Katagiri C, Kobayashi Y, Higashi S, Okuda T (2008) Establishment of a rearing system of the extremotolerant Tardigrade Ramazzottius varieornatus: a new model animal for astrobiology. Astrobiology 8:549-556 
Horning D, Schuster R, Grigarick A (1978) Tardigrada of New Zealand. New Zeal J Zool 5:185-280

Iharos G (1963) The zoological results of Gy. Topal's collections in South Argentina, 3. Tardigrada. Ann Hist Natur Ms Nat Hung Budapest 55:293-299

Jerez Jaimes JH, Narváez Parra EX (2001) Tardigrados (Animalia, tardigrada) de la Reserva El Diviso - Santander, Colombia. Biota Colomb 2:145-151

Johansson C, Miller WR, Linder ET, Adams BJ, Boreliz-Alvarado E (2013) Tardigrades of Alaska: distribution patterns, diversity and species richness. Polar Res 32:18793

Kaczmarek $Ł$, Michalczyk $Ł$ (2006) Tardigrada fauna of Mongolia (Central Asia) with a description of Isohypsibius altai sp. nov. (Eutardigrada: Hypsibiidae). Zool Stud 45(1):11-23

Kaczmarek $Ł$, Michalczyk $Ł$ (2007) A new species of Tardigrada (Eutardigrada: Milnesiidae): Milnesium krzysztofi from Costa Rica (Central America). New Zeal J Zool 34:297-302

Kaczmarek $Ł$, Michalczyk $Ł$ (2009) Two new species of Macrobiotidae, Macrobiotus szeptyckii (harmsworthi group) and Macrobiotus kazmierskii (hufelandi group) from Argentina. A Zool Crac 52B:87-99

Kaczmarek $Ł$, Michalczyk $Ł$, Beasley CW (2004) Milnesium katarzynae sp. nov. a new species of eutardigrade (Milnesiidae) from China. Zootaxa 743:1-5

Kaczmarek $Ł$, Jakubowska N, Michalczyk $Ł$ (2012a) Current knowledge on Turkish tardigrades with a description of Milnesium beasleyi sp. nov. (Eutardigrada: Apochela: Milnesiidae, the granulatum group). Zootaxa 3589:49-64

Kaczmarek $Ł$, Zawierucha K, Smykla J, Michalczyk $Ł$ (2012b) Tardigrada of the Revdalen (Spitsbergen) with the descriptions of two new species: Bryodelphax parvuspolaris (Heterotardigrada) and Isohypsibius coulsoni (Eutardigrada). Polar Biol 35:1013-1026

Kaczmarek Ł, Michalczyk Ł, McInnes SJ (2014a) Annotated zoogeography of non-marine Tardigrada. Part I: Central America. Zootaxa 3763(1):1-62

Kaczmarek Ł, Cytan J, Zawierucha K, Diduszko D, Michalczyk $Ł$ (2014b) Tardigrades from Peru (South America), with descriptions of three new species of Parachela. Zootaxa 3790(2):357-379

Kinchin IM (1990) The cosmopolitan tardigrade Milnesium tardigradum Doyère: an observation from Northern Ireland. Microscopy 36:412-414

Land M, Musto A, Miller WR, Starkey DE, Miller JD (2012) Tardigrades of the University of Central Arkansas Campus, Conway, AR. Southeast Nat 11 (3):469-476

Lemloh ML, Brummer F, Schill RO (2011) Life-history traits of the bisexual tardigrades Paramacrobiotus tonollii and Macrobiotus sapiens. J Zool Syst Evol Res 49(S1):58-61

Lisi O (2011) Remarks on Doryphoribius flavus (Iharos, 1966), and description of three new species (Tardigrada, Hypsibiidae). Zootaxa 2834:17-32

Lisi O, Londoño R, Quiroga S (2014) Tardigrada from a sub-Andean forest in the Sierra Nevada de Santa Marta (Colombia) with the description of Itaquascon pilatoi sp. nov. Zootaxa 3841(4):551-562

Marcus E (1936) Tardigrada. Das Tierreich 66:1-340

Marley NJ (2006) A new species of Tardigrada, Platicrista ramsayi sp. nov. from the páramo of Volcán Chiles, Ecuador. Zootaxa 1166:35-48

Marley NJ, McInnes SJ, Sands CJ (2011) Phylum Tardigrada: a re-evaluation of the Parachela. Zootaxa 2819:51-64

Maucci W (1988) Tardigrada from Patagonia (Southern South America) with description of three new species. Rev Chilena Entomol 16:5-13

Maucci W (1991) Tre nuove specie di eutardigradi della Groenlandia meridionale. Boll Mus Civ St Nat Verona 15:279-289

Maucci W (1996) Tardigrada of the Arctic tundra with description of two new species. Zool J Linn Soc 116:185-204

Mclnnes SJ (1994) Zoogeographic distribution of terrestrial/freshwater tardigrades from current literature. J Nat Hist 28:257-352

Mclnnes SJ, Chown SL, Dartnall JG, Pugh PJA (2001) Milnesium cfr. tardigradum (Milnesiidae, Apochela, Tardigrada): a monitor high altitude meiofauna on sub-Antarctic Marion Island. Zool Anz 240:461-465

Melo JC, Beltrán-Pardo E, Bernal JE, Kaczmarek $Ł$ (2014) New records of tardigrades from Colombia (Guatavita, Cundinamarca Department). Turk J Zool 38:1-9. doi:10.3906/zoo-1405-13

Meyer HA (2013) Terrestrial and freshwater Tardigrada of the Americas. Zootaxa 3747:1-71

Meyer HA, Hinton JG (2010) Milnesium zsalakoae and M. jacobi, two new species of Tardigrada (Eutardigrada: Apochela: Milnesiidae) from the southwestern United States. Proc Biol Soc Wash 123:113-120

Meyer HA, Hinton JG (2012) Terrestrial Tardigrada of the Island of Barbados in the West Indies, with the description of Milnesium barbadosense sp. $\mathrm{n}$. (Eutardigrada: Apochela: Milnesiidae). Caribb J Sci 46(2-3):194-202
Meyer HA, Hinton JG, Dupré MC (2013) Milnesium lagniappe, a new species of water bear (Tardigrada, Eutardigrada, Apochela, Milnesiidae) from the southern United States. West N Am Naturalist 73(3):295-301

Meyer HA, Domingue MN, Hinton JG (2014) Tardigrada of the west Gulf Coastal Plain, with descriptions of two new species from Louisiana. Southeast Nat 13(5):117-130

Michalczyk $Ł$, Kaczmarek $Ł$ (2003) Minibiotus constellatus, a new species of Tardigrada from Peru (Eutardigrada: Macrobiotidae). Genus 14:295-305

Michalczyk $Ł$, Kaczmarek $Ł$ (2004) Minibiotus eichhorni sp. nov., a new species of eutardigrade (Eutardigrada: Macrobiotidae) from Peru. Ann Zool 54:673-676

Michalczyk $Ł$, Kaczmarek $\measuredangle$ (2005) The first record of the genus Calohypsibius Thulin, 1928 (Eutardigrada: Calohypsibiidae) from Chile (South America) with description of a new species Calohypsibius maliki. New Zeal J Zool 32:287-292

Michalczyk $Ł$, Kaczmarek $Ł$ (2006) Revision of the Echiniscus bigranulatus group with a description of a new species Echiniscus madonnae (Tardigrada: Heterotardigrada: Echiniscidae) from South America. Zootaxa 1154:1-26

Michalczyk $Ł$, Kaczmarek $Ł$ (2013) The Tardigrada Register: a comprehensive online data repository for tardigrade taxonomy. J Limnol 72(S1):175-181

Michalczyk $Ł$, Wełnicz W, Frohme M, Kaczmarek $Ł$ (2012a) Redescriptions of three Milnesium Doyère, 1840 taxa (Tardigrada: Eutardigrada: Milnesiidae), including the nominal species for the genus. Zootaxa 3154:1-20

Michalczyk $Ł$, Wełnicz W, Frohme M, Kaczmarek $Ł$ (2012b) Corrigenda of Zootaxa, 3154:1-20 Redescriptions of three Milnesium Doyère, 1840 taxa (Tardigrada: Eutardigrada: Milnesiidae), including the nominal species for the genus. Zootaxa 3393:66-68

Mihelčič F (1967) Ein Beitrag zur Kenntnis der Tardigraden Argentiniens. Verh Zool-Botan Ges Wien 107:43-56

Mihelčič F (1972) Ein weiterer Beitrag zur Kenntnis der Tardigraden Argentiniens. Verh Zool-Botan Ges Wien 110(111):47-52

Miller WR, Williams S (2012) A note on a Greenland tardigrade: Milnesium eurystomum Maucci, 1991 eating an amoeba. Trans Kans Acad Sci 115(1-2):26-27

Moly de Peluffo MC, Peluffo JR, Rocha AM, Doma IL (2006) Tardigrada distribution in a medium-sized city of the central Argentina. Hydrobiologia 558:141-150

Montoya E, Rull V, van Geel B (2010) Non-pollen palynomorphs from surface sediments along an altitudinal transect of the Venezuelan Andes. Palaeogeogr Palaeocl 297:169-183

Murray J, Wailes GH (1913) Notes on the natural history of Bolivia and Peru. Scott Oceanogr Lab, Edinburgh, pp 1-45

Nederström P (1919) Die bis jetzt aus Finland bekannten Tardigraden. A Soc Fauna Flora Fenn 46(8):1-25

Nelson DR, Horning DS (1979) Tardigrada of the Kowhai Bush, Kaikoura, New Zealand. Zesz Nauk Univ Jagiell 25:125-142

Nelson DR, Guidetti R, Rebecchi L (2010) Tardigrada. In: Thorp JH, Covich AP (eds) Ecology and Classification of North American Freshwater Invertebrates, vol 3E. Academic Press (Elsevier), San Diego, pp 455-484

Nickel K, Miller WR, Marley N (2001) Tardigrades of South America: Machu Picchu and Ollantayambo, Peru. Zool Anz 240:505-509

Özdikmen H (2008) Bertolanius nom. nov., a replacement name for the genus Amphibolus Bertolani, 1981 (Tardigrada: Parachela) with type species designation. Mun Ent Zool 3(1):330-332

Peel MC, Finlayson BL, McMahon TA (2007) Updated world map of the Köppen-Geiger climate classification. Hydrol Earth Syst Sc 11:1633-1644, http://dx.doi.org/10.5194/ hess-11-1633-2007

Peluffo JR, Moly de Peluffo MC, Rocha AM (2002) Rediscovery of Echiniscus rufoviridis du Bois-Reymond Marcus, 1944. (Heterotardigrada, Echiniscidae) New contributions to the knowledge of its morphology, bioecology and distribution. Gayana 66:97-101

Peluffo JR, Rocha AM, Moly de Peluffo MC (2007) Species diversity and morphometrics of tardigrades in a medium-sized city in the Neotropical Region: Santa Rosa (La Pampa, Argentina). Anim Biodivers Conserv 30:43-51

Pilato G (1981) Analisi di nuovi caratteri nello studio degli Eutardigradi. Animalia $8: 51-57$

Pilato G (2000) Macrobiotus centesimus, new species of eutardigrade from the South America. Boll Accad Gioenia Sci Nat Catania 33:97-101

Pilato G (2007) Echiniscus quitensis, a new species of tardigrade from Ecuador (Heterotardigrada: Echiniscidae). Zootaxa 1389:55-60 
Pilato G, Binda MG (1991) Milnesium tetralamellatum, new species of Milnesiidae from Africa (Eutardigrada). Trop Zool 4:103-106

Pilato G, Binda MG (1994) Dactylobiotus caldarellai, nuova specie di Eutardigrado della Terra del Fuoco. Animalia 21:87-91

Pilato G, Binda MG (1996) Mixibius fueginus, nuova specie di eutardigrado della Terra del Fuoco. Boll Accad Gioenia Sci Nat Catania 29(351):27-32

Pilato G, Binda MG (1998) A comparison of Diphascon (D.) alpinum Murray, 1906 D. (D.) chilenense Plate, 1889 and D. (D.) pingue Marcus, 1936 (Tardigrada), and description of a new species. Zool Anz 236:181-185

Pilato G, Binda MG (2001) Biogeography and limno-terrestrial tardigrades: are they truly incompatible binomials? Zool Anz 240:511-516

Pilato G, Patanè M (1998) Macrobiotus ovostriatus, a new species of eutardigrade from Tierra del Fuego. Boll Acc Gioenia Sci Nat Catania 30(353):263-268

Pilato G, Binda MG, Qualtieri F (1998) Diphascon (Diphascon) mitrense, new species of eutardigrade from Tierra del Fuego. Boll Acc Gioenia Sci Nat Catania 31:101105

Pilato G, McInnes SJ, Lisi O (2012) Hebesuncus mollispinus (Eutardigrada, Hypsibiidae), a new species from maritime Antarctica. Zootaxa 3446:60-68

Pilato G, Binda MG, Napolitano A, Moncada E (2000) The specific value of Macrobiotus coronatus De Barros 1942, and description of two new species of the harmsworthi group (Eutardigrada). Boll Acc Gioenia Sci Nat Catania 33:103-120

Pilato G, Binda MG, Napolitano A, Moncada E (2001) Notes on South American tardigrades with the description of two new species: Pseudechiniscus spinerectus and Macrobiotus danielae. Trop Zool 14:223-231

Pilato G, Binda MG, Lisi O (2002) Notes on tardigrades of the Seychelles with the description of two new species. Boll Sedute Accad Gioenia Sci nat Catania 35:503-517

Pilato G, Binda MG, Lisi O (2003) Remarks on some species of tardigrades from South America with description of Minibiotus sidereus n. sp. Zootaxa 195:1-8

Pilato G, Binda MG, Napolitano A, Moncada E (2004) Remarks on some species of tardigrades from South America with description of two new species. J Nat Hist 38:1081-1086

Poprawa I (2005) The ovary structure, previtellogenic and vitellogenic stages in parthenogenetic species Dactylobiotus dispar (Murray, 1907) (Tardigrada: Eutardigrada). Tissue Cell 37(5):385-392

Poprawa I (2011) Ultrastructural studies of the formation of the egg capsule in the hermaphroditic species, Isohypsibius granulifer granulifer Thulin, 1928 (Eutardigrada: Hypsibiidae). Zool Sci 28(1):37-40

Rahm G (1931) Tardigrada of the South of America. Rev Chil Hist Nat 35:118-141

Rahm G (1932) Freilebende Nematoden, Rotatorien und Tardigraden aus Südamerika (besondersaus Chile). Zool Anz 98:94-112 and 113-128

Ramazzotti G (1957) Due nuove specie di Tardigradi extra-europei. Atti Soc Ital Sci Nat Mus Civ Stor Nat Milano 96:188-191

Ramazzotti G (1962) Tardigradi del Cile, con descrizione di quattro nuove specie e di una nuova varieta. Atti Soc Ital Sci Nat Mus Civ Stor Nat Milano 101:275-287

Ramazzotti G (1964) Tardigradi del Cile Il, con descrizione di due nuove specie e note sulla scultura degli Echiniscidae. Atti Soc Ital Sci Nat Mus Civ Stor Nat Milano 103:89-100

Ramazzotti G, Maucci W (1983) II Phylum Tardigrada. III edizione riveduta e aggiornata. Mem Ist Ital Idrobiol 41:1-1012

Richters F (1903) Nordische Tardigraden. Zool Anz 27:168-172

Richters F (1911) Südamerikanische Tardigraden. Zool Anz 38:273-277

Richters F (1926) Tardigrada. In: By Kükenthal W, Krumbach T (eds) Handbuch der Zoologie, vol 3. Walter de Gruyter \& Co, Berlin and Leipzig, pp 58-61

Rossi GC, Claps MC (1980) Contribucion al conocimiento de los tardigrados de Argentina. I. Rev Soc Ent Argent 39:243-250

Rossi GC, Claps MC (1989) Contribucion al conocimiento de los Tardigrados de la Argentina V. Rev Soc Ent Argent 47:133-142

Rossi GC, Claps MC (1991) Tardigrados dulceacuicolas de la Argentina. Faun Aqu Repub Argent 19:1-70

Rossi G, Claps M, Ardohain D (2009) Tardigrades from northwestern Patagonia (Neuquén Province, Argentina) with the description of three new species. Zootaxa 2095:21-36

Schill RO (2013) Life-history traits in the tardigrade species Paramacrobiotus kenianus and Paramacrobiotus palaui. J Limnol 72(S1):160-165

Schill RO, Jonsson Kl, Pfannkuchen M, Brummer F (2011) Food of tardigrades: a case study to understand food choice, intake and digestion. J Zool Syst Evol Res 49(S1):66-70
Schultze CAS (1834) Macrobiotus Hufelandii animal e crustaceorum classe novum, reviviscendi post diuturnam asphyxian et ariditaten potens, etc. 8 Seiten, 1 tab. C. Curths, Berlin.

Schuster RO, Nelson DR, Grigarick AA, Christenberry D (1980) Systematic criteria of the Eutardigrada. Trans Am Microsc Soc 99:284-303

Séméria Y (1993) Description d'une nouvelle de Tardigrade du Vénézuéla Ramazzottius edmondabouti n. sp. (Eutardigrada, Hypsibiidae). Bull Mens Soc Linn Lyon 62:215-216

Shaw MW, Miller WR (2013) Tardigrades of North America: a preliminary survey of New Jersey, U.S.A. Newslet New York Microscop Soc 7(27,8):36-56

Sudzuki M (1964) On the microfauna of the Antarctic Region. I. Moss-water community at Langhovde. Sci Rep Ser E 19:1-4

Suzuki AC (2003) Life history of Milnesium tardigradum Doyere (Tardigrada) under the rearing environment. Zool Sci 20(1):49-57

Szymańska B (1994) The Tardigrada from Axel Heiberg Island and the associate bryophyte species. Folia Entom Hung 55:359-368

Trygvadóttir BV, Kristensen RM (2013) A zoogeographic study of the limnoterrestrial tardigrade fauna on the Faroe islands. J Limnol 72(S1):113-122

Tumanov D (2006) Five new species of the genus Milnesium (Tardigrada, Eutardigrada, Milnesiidae). Zootaxa 1122:1-23

Vicente F, Bertolani R (2013) Considerations on the taxonomy of the Phylum Tardigrada. Zootaxa 3626(2):245-248

Wallendorf M, Miller WR (2009) Tardigrades of North America: Milnesium alabamae nov. sp. (Eutardigrada: Apochela: Milnesiidae) a new species from Alabama. Trans Kans Acad Sci 112:181-186

Yang T (2003) Two new species and three new records of the Tardigrada (Heterotardigrada, Echiniscidae; Eutardigrada, Milnesiidae, Macrobiotidae, Hypsibiidae). A Zootax Sin 28:235-240

Yin H, Li X (2011) New records of tardigrades (Tardigrada) from Taiwan. J Shaanxi Normal Univ Nat Sci Ed 39(4):55-59

Zawierucha K, Coulson SJ, Michalczyk L, Kaczmarek L (2014) Current knowledge of the Tardigrada of Svalbard with the first records of water bears from Nordaustlandet (High Arctic). Polar Res 32:20886, doi.org/10.3402/polar. v32i0.20886

\section{Submit your manuscript to a SpringerOpen ${ }^{\odot}$ journal and benefit from:}

- Convenient online submission

$\checkmark$ Rigorous peer review

- Immediate publication on acceptance

- Open access: articles freely available online

- High visibility within the field

- Retaining the copyright to your article

Submit your next manuscript at $>$ springeropen.com 